\title{
Economic uncertainty, parental selection, and the criminal activity of the 'children of the wall'
}

Citation for published version (APA):

Chevalier, A., \& Marie, O. (2013). Economic uncertainty, parental selection, and the criminal activity of the 'children of the wall'. Maastricht University, Graduate School of Business and Economics. GSBE Research Memoranda No. 066 https://doi.org/10.26481/umagsb.2013066

Document status and date:

Published: 01/01/2013

DOI:

10.26481/umagsb.2013066

Document Version:

Publisher's PDF, also known as Version of record

\section{Please check the document version of this publication:}

- A submitted manuscript is the version of the article upon submission and before peer-review. There can be important differences between the submitted version and the official published version of record.

People interested in the research are advised to contact the author for the final version of the publication, or visit the DOI to the publisher's website.

- The final author version and the galley proof are versions of the publication after peer review.

- The final published version features the final layout of the paper including the volume, issue and page numbers.

Link to publication

\footnotetext{
General rights rights.

- You may freely distribute the URL identifying the publication in the public portal. please follow below link for the End User Agreement:

www.umlib.nl/taverne-license

Take down policy

If you believe that this document breaches copyright please contact us at:

repository@maastrichtuniversity.nl

providing details and we will investigate your claim.
}

Copyright and moral rights for the publications made accessible in the public portal are retained by the authors and/or other copyright owners and it is a condition of accessing publications that users recognise and abide by the legal requirements associated with these

- Users may download and print one copy of any publication from the public portal for the purpose of private study or research.

- You may not further distribute the material or use it for any profit-making activity or commercial gain

If the publication is distributed under the terms of Article $25 \mathrm{fa}$ of the Dutch Copyright Act, indicated by the "Taverne" license above, 


\section{Maastricht University}

Arnaud Chevalier, Olivier Marie

Economic uncertainty, parental selection, and the criminal activity of the 'children of the wall'

RM/13/066

\section{GSBE}

Maastricht University School of Business and Economics

Graduate School of Business and Economics

P.O Box 616

NL- 6200 MD Maastricht

The Netherlands 


\title{
ECONOMIC UNCERTAINTY, PARENTAL SELECTION, AND THE CRIMINAL ACTIVITY OF THE 'CHILDREN OF THE WALL'*
}

\author{
Arnaud Chevalier and Olivier Marie ${ }^{+}$
}

October 2013

\begin{abstract}
We explore the link between parental selection and criminality of children in a new context. After the collapse of the Berlin Wall in 1989, East Germany experienced a very large, but temporary, drop in birth rates mostly driven by economic uncertainty. We exploit this natural experiment in a differences in differences setup to first estimate that the children from these affected (smaller) cohorts are relatively much more likely to be criminally active. Using individual level data, we provide evidence that women who gave birth in at this period of uncertainty were negatively selected into fertility. Further investigation of the underlying mechanisms reveals that emotional attachment and intergenerational transmission of risk attitudes play important roles in the parental selection-crime of children relationship. Finally, results for siblings support a causal interpretation of our findings.
\end{abstract}

JEL codes: J13, K42

Keywords: Crime, parental selection, fertility decision, economic uncertainty, risk attitude

* Chevalier would like thank the British Academy (MD133047) and GSBE (M.11.5122) for grants which made this research possible. Marie is grateful for financial support from the Netherlands Organization for Scientific Research (NWO 451.12.005). We thank Thomas Dohmen, Nicola Fuchs-Schündeln, Christian Traxler, Tanya Wilson, Justin Wolfers and participants at workshops at the IZA-ESSLE, Frankfurt- $5^{\text {th }}$ TWEoE, NBER-SI, Science Po/Chicago and seminars in Cologne, Bocconi, Erasmus, Hamburg, Maastricht, Munich, PUC-RIO, Stirling, Stockholm, and Wuerzburg for their comments.

\footnotetext{
${ }^{+}$Corresponding Author: Department of Economics, Maastricht University, P.O. Box 616, 6200 MD Maastricht, The Netherlands. Tel: +31 433884605 Email: o.marie@maastrichtuniveristy,nl
} 


\section{Introduction}

Cohort composition, as well as its size, may affect cohort outcomes. A prime example of the effect of parental selection is provided by the legalization of abortion in the U.S. in the Seventies, which has been associated with reduction in welfare recipiency (Gruber, Levine and Staiger [1999]), drug use (Charles and Stevens [2006]) and teenage motherhood (Donohue, Grogger and Levitt [2009]). Controversially, Donohue and Levitt (2001) argue that the legalization of abortion was responsible for up to half of the drop in crime observed in the Nineties. The suggested mechanism is that fewer "unwanted" children, who would have had a greater probability of participating in these negative outcomes, were born. As such the resulting cohorts were positively selected; i.e., the mean characteristics of parents were better after abortion became legal. Note, however, that the opposite selection was found in Romania for cohorts affected by a repeal of the abortion legislation (Pop-Eleches [2006]) suggesting that in this context poorer, less educated women may have been constrained in their access to abortion.

The controversy surrounding Donohue and Levitt's finding suggests that it is unclear whether changes in abortion legislation can be used to identify changes in long term trends in criminal activity. First, Donohue and Levitt (2001) rely on the ratio of abortion to birth to approximate the fraction of unwanted children, but this ignores that abortion was possible even when illegal. Additionally, the legalization of abortion, by reducing the marginal costs of pregnancy, increases the number of conceptions, thus affecting the numerator of the abortion ratio. As Ananat et al. (2009) show, while the change in the availability of legal abortion is potentially exogenous, the abortion ratio is not. Second, it is not possible to differentiate positive parental selection from a cohort size effect which goes in the same direction; i.e., a smaller but better endowed cohort is compared to a larger one with worse observed parental characteristics. As such the reported estimate is an upper bound of the effect of parental 
selection, and indeed Pop-Eleches (2006) observes that half of the parental selection effect observed in Romania stems from the crowding out of public resources for the larger cohorts born after the abortion ban. Third, relying on small differences in the timing of the repeal of anti-abortion laws between States ${ }^{1}$ after which all cohorts are 'treated' makes it difficult to separate time trends from the actual policy effects. Fourth, neither the argument about "unwanted children” nor the mechanisms by which parental selection affects the children outcomes have so far been substantiated, due to lack of appropriate data. As such, the literature, and especially the validity of Donohue and Levitt's findings on the effect of abortion on crime have been hotly debated and seriously questioned in a number of subsequent articles ${ }^{2}$.

In this paper we propose a novel identification strategy which sidesteps these problems. Instead of changes to abortion law we rely on a large economic uncertainty shock which dramatically reduced fertility and affected cohort composition, temporary and locally. More precisely, we exploit the large drop in fertility in East Germany following the collapse of the Berlin Wall ${ }^{3}$. Over a three-year period the fertility rate in the former East Germany was more than halved, an unprecedented peace-time event, before returning to trend. Throughout the manuscript we refer to the cohorts born in the eastern Länder ${ }^{4}$ between 1991 and 1993 as the 'Children of the Wall' (CoW).

\footnotetext{
${ }^{1}$ Abortion became legally available in 1970 in five States (Alaska, California, Hawaii, New York and Washington) while the rest of the country waited until the ruling of the Supreme Court in "Roe vs Wade" of 1973 to make it legal.

${ }^{2}$ Rather than using the abortion ratio, Joyce (2004) estimates a reduced form model and, after controlling for State specific trends, reports no significant effect of abortion on future crime. Cook and Laub (2002) question the timing implied by Donohue and Levitt (2001) and note that the crime reduction appears to start too late to be driven by the abortion reform, while Foote and Goetz (2003) and Joyce (2009) are unable to replicate Donohue and Levitt's findings even using the same specification. These concerns were mostly addressed in responses by Donohue and Levitt $(2004,2008)$ and their results have been somewhat confirmed for Canada (Sen [2007]).

${ }^{3}$ An early example of the impact of social change on fertility is provided in Rindfuss et al (1978) who document the effect of Brown vs Board of Education in 1954 which declared school segregation illegal. This Supreme Court decision would have affected children being schooled in States still practicing discrimination; i.e. Southern States. This social change led to a drop in the number of white birth in the South of $0.7 \%$ in 1955 while birth numbers were increasing by close to $2 \%$ nationally.

${ }^{4}$ Throughout the paper, we will use interchangeably "Land" or "State" to refer to the 16 constituent states of the Federal Republic of Germany. Note also that the plural of Land is Länder.
} 
The effect of the socio-economic upheavals following the collapse of the East German regime on fertility decision and parental selection is a priori ambiguous, since the substitution and income effects of female earnings push the demand for children in different directions. In practice, there is a relative consensus on the existence of a pro-cyclical pattern in fertility (see Sobotka, Skirbekk, and Philipov [2011] for a review). There is however far less evidence of parental selection with regard to the business cycle. Dehejia and Lleras-Muney (2004) suggest positive selection into motherhood in terms of education and marital status; i.e. parental selection is pro-cyclical. We can expect, and we document, that the parents who decided to give birth in former East Germany during the period of great economic uncertainty following the reunification of Germany were negatively selected. Additionally, we show that the fertility drop is not due to a change in abortion behavior but mostly driven by a reduction in conception. Like Donohue and Levitt (2001) we first focus on the criminal activity of children as a strong revelator of parental selection. This is a relevant proxy for parental selection since: i. the determinants of selection into fertility and offending participation of children are correlated (Sampson and Laub [1993]); ii. criminality can be transmitted between generations (Hjalmarsson and Lindquist [2012]) and; iii. a small number of individuals can be responsible for a large fraction of crimes (Tracy, Wolfgang and Figlio [1990]).

Second, since the cohorts we are interested in are much smaller than usual, we can immediately reject any crowding out effect and in contrast would expect the small cohort size to positively impact outcomes such as education. Consequently, if parental selection is proved to be negative for these children, the parental selection and cohort size effects go in opposite directions and our results should be interpreted as lower bound estimates of the true effect of parental selection.

Third, the natural experiment we exploit led to a very profound but short-lived exogenous fertility shock in former East Germany only, which creates clear pre- and post- 
cohorts. Moreover, no drop in fertility was observed in the former West Germany, which can then be considered a natural control since those born on either side of the "border" where subject to ever more similar educational and socio-economic environments when growing up in re-unified Germany. This group enables us to credibly account for the potential effect of shared macro shocks, under the assumption that the two parts of the country face a common crime trend, which we show mostly holds. We thus use a differences in differences estimator, whereby the criminal activity of children growing up in the eastern part of the reunified country is compared to the one for those growing up in the western part, over time. Moreover, we have detailed measures of arrest for different age groups by state (Land) which allows us to account for unobservable characteristics at the state level, such as policing strategy, that would affect the probability of arrest at a given period. As such, we can clearly separate a cohort effect from trends in arrest.

The literature on parental selection has been plagued by the inability to comprehensively document the parents' characteristics or the mechanism whereby they may lead to specific outcomes for children. Having documented the impact of parental selection on criminal activity, our fourth contribution to the literature is to fill this gap by exploiting very rich individual level data with information on mother and child characteristics, in order to expand the knowledge on the mechanisms through which parental selection affects the offending behavior of future cohorts. This data allows us to consider the previously used maternal characteristics (age, education, marital status, and employment) to establish the direction of the selection into fertility, but we also expand on two previously overlooked sets of characteristics: i) maternal emotional attachment and parenting competence as expressed by children themselves and ii) risk attitude of both mothers and children. We believe these to be potentially crucial pieces of the fertility-crime puzzle since i) reveals parental quality more objectively and ii) risk preference could influence both fertility of the mothers and offending 
decisions of the children. As such we document more precisely the parental selection and assess potential mechanisms by which it affects children's outcomes. Additionally, we propose a simple test on whether the observed effects for children are driven by positive/negative parental selection or just being born at a particular good/bad economic time. For example, the fetal programming hypothesis asserts that parental stress while in the womb can lead to abnormal emotional control (see van den Bergh et al. [2005] for a review), that itself could lead to negative outcomes even without parental selection (see Aizer, Stroud and Buka [2009] for example). We test whether such a mechanism is at play here by focusing on key outcomes of the siblings of the 'Children of the Wall'. These older brothers and sisters would be expected to score similarly on evaluation of parental skills and risk attitude if those are driven by parental selection and not by being born in a particular environment.

Our main empirical analysis and the ensuing findings developed in the paper are the following. We first clearly document the unprecedented drop in birth rate observed in East Germany just after the fall of the Berlin Wall ${ }^{5}$ and give a number of explanations as to why it happened in the context of the historical and institutional background; one of the main reason appears to be the fear of the economic uncertainty following reunification.

Unfortunately, no dataset includes both crime and parental information, therefore we rely on two sources of data. We use administrative information at the Land level, to build a panel dataset on age-group arrests by Land, year and cohorts. Adopting a differences in differences strategy, we show that the offending behavior of the 'Children of the Wall' is much worse than that of previous cohorts. We estimate that the CoWs exhibit arrest rates at least 40 percent higher than comparable peers and that this is spread across most crime types, and holds for both genders. Moreover, the differences in criminal activity start appearing at a young age - as early as age 6 . These findings are confirmed in a large number of alternative

\footnotetext{
${ }^{5}$ Other East-European countries also experienced drops in fertility following the collapse of the communist regimes in place however their magnitudes were substantially smaller than that observed in East Germany (UNECE, [2000]).
} 
specification and robustness checks which enable us to reject that the results are driven by time specific unobservable characteristics.

These findings are in line with the results of Donohue and Levitt (2001) and consistent with negative parental selection. Using individual level survey data from the German Socioeconomic Panel (GSOEP) we report strong evidence of negative selection of women who chose to give birth in East Germany just after the end of the communist regime. These women were on average younger, less educated, more likely to be single and economically inactive. Moreover, their children rate their relationship with their mothers and how supportive their mothers were, very badly: they are 11 to 14 percentage points less likely to say that their mother is an important person in their life, or that she loves them, and CoWs are $30 \%$ less likely to think they are receiving adequate support from their mothers. We interpret this as corroborating the bad parenting explanation which is often put forward in the abortioncrime literature or the long-term effect of early rearing conditions (Conti et al. [2012]). This is nonetheless quite a surprising finding as we would have expected these children to be 'wanted' since there was no barrier to using most forms of birth control. This conundrum may be explained by differences in risk preference. We find that the women who had children during the very uncertain years after the fall of the Berlin Wall are much more willing to take risk, and especially what we define as 'bad' types of risk. This may well explain why they made what were with hindsight relatively sub-optimal fertility decisions, and end up being relatively poor mothers to the children they chose to have.

We also show that the 'Children of the Wall' themselves have much higher willingness to take risk which could explain their higher than expected offending propensity. This result fits well with recent evidence on inter-generational risk attitude transmission (Dohmen et al., [2012]) and is perhaps one of the crucial pieces in understanding the fertilitycrime relationship puzzle. While no crime participation date is available in the GSOEP, we 
show that on other outcomes, including schooling which is traditionally correlated with criminal participation, CoW perform worse than their peers.

Finally, we reject the possibility that these children have worse outcomes due to being born in bad economic times. The CoWs' siblings also report a similarly poor relationship with their mothers and are also much more willing to take risk, which is consistent with a parental fixed effect of poor parenting skills. The CoWs negative outcomes are thus driven by the higher fraction of parents with poor parenting skills in this cohort compared to previous (and subsequent) cohorts.

Our findings confirm, as conjectured by Donohue and Levitt (2001), that parental selection may be one of the best predictors of the future criminality of a cohort, and that this most likely works through quality of parenting and risk attitude transmission. These conclusions have potentially important policy implications. First, provision of public services (school places, police numbers, etc) should not only be based on the size of an incoming cohort, and more attention should be paid on its composition. Second, since the effects on criminal behavior start appearing as early as age six, it calls for targeted interventions from a very young age since this is when preferences are still malleable (Heckman et al. [2010]). The right target group of children is however difficult to identify since parenting skills or a generalized measure of risk attitude are typically not observed.

The rest of the paper is structured as follows. Section 2 goes over the institutional background surrounding the period of the fertility drop we exploit as a natural experiment and considers various possible explanations on why the fertility dropped. Section 3 describes the various datasets used and specifies the differences-in-differences strategy we adopt throughout. Section 4 presents the arrest results for the 'Children of the Wall'. Section 5 reports our finding regarding the mechanisms at work behind the fertility crime-relationship using individual level data. Section 6 offers concluding remarks. 


\section{Institutional Background and the Fertility Drop}

\subsection{East Germany and the German re-unification}

In the aftermath of World War II, Germany was split along the positions of the occupying armies with the Federal Republic of Germany (FRG or West Germany) and the German Democratic Republic (GDR or East Germany) being officially founded in 1949. The GDR developed as one of the most orthodox of the former European Communist regimes. As the two countries' economic and political performances diverged, more and more citizens from East Germany migrated by crossing the border into West Berlin. To stop this exodus, a wall was built around the western part of the city in 1961. The Berlin Wall became the symbol of the forty year physical and socio-economic separation of a people which had previously shared a common destiny.

By the end of the 1980s, a series of sudden and radical political changes led to the rapid collapse of the communist regimes in most of Eastern Europe. In the GDR large demonstrations against the regime started in September 1989 and emblematically culminated with the televised destruction of the Berlin Wall on the evening of the $9^{\text {th }}$ November 1989 , as the borders between East and West Germany were declared opened. There was a strong political will to quickly re-unite the two countries. By July 1990, a common currency was introduced and re-unification was completed less than a year later in October 1990 (see for example, Judt [2005] for details). The very abrupt end of almost half a century of communist rule and the express re-unification that followed was a huge unexpected shock and led to a period of great socio-economic uncertainties for the citizen of the new East-German Länder ${ }^{6}$.

\footnotetext{
${ }^{6}$ We are not the first to use German re-unification as a natural experiment to investigate the occupational effect on precautionary (Fuchs-Schündeln and Schündeln [2005]) and household saving (Fuchs-Schündel [2008]), preference for redistribution (Alesina and Fuchs-Schündeln [2007]), consumption behaviour (Bursztyn and
} 
This was perhaps best reflected by the massive fall in the number of births that occurred there in the years just after the fall of the Berlin Wall.

\subsection{The Fertility Drop}

Figure 1 shows the crude birth rate (per 1,000 women) between 1950 and 2008 for East and West Germany. The first thing to note is that, while at a somewhat lower level in the East, the trends in fertility up to 1989 were very similar in both countries: a post-war baby boom until the mid-1960s, a rapid decrease (readjustment) in the following decade, and a relative stabilization between 1970 and 1990. The somewhat larger increase in fertility in East Germany starting in 1974 was the result of the adoption of pro-natal policies, providing a range of welfare benefits to parents (see Reinheckel et al. [1998] for details). However these policies only had a temporary effect so that by the mid-Eighties, fertility trends in both countries were similar. What stands out in Figure 1 is the massive and temporary collapse in birth rates in the East, but not in the West, following the fall of the Berlin Wall. It has been defined by demographers as the "most substantial fall in birth rates that ever occurred in peacetime" (Conrad, Lechner and Werner [1996], p.331). Within a year, the birth rate dropped by 40 percent and reached an all-time low in 1993, when it was only half of its 1989 level. This fertility drop was relatively short lived, and a strong recovery started in 1994.

[Figure 1 about here]

To better illustrate the sharp deviation from trend that occurred in East Germany after the end of Communism, Figure 2 depicts annual changes in the crude birth rate between East and West Germany; i.e. yearly differences-in-differences coefficients. The horizontal line 
defines years with no difference in the changes in crude birth rates between the two countries. In the forty years up to the fall of the Berlin Wall (denoted by the vertical line in 1990), this gap never exceeded + or -15 percent. The difference in crude birth rate evolution after this is striking. While West Germany carries on trend, East Germany deviates by 50 percent in the year following the end of communism before catching up from 1994. Figure 2 clearly illustrates two important points that are relevant to our identification: i) pre-1990, fertility trends were consistently similar between East and West ii) the fertility drop affecting East Germany after the collapse of the Wall was short-lived and fertility started recovering within three years. As such, we define as 'Children of the Wall', the cohorts of individuals born between 1991 and 1993 in the Eastern Länder.

[Figure 2 about here]

Finally, to more precisely link the timing of the fertility drop to the regime change in East Germany, we consider, in Figure 3, the monthly number of births for the two regions. The data is only available from January 1990 onwards but we observe that the number of births only started to sharply fall in August of that year, that the number of births in East Germany stops falling in early $1994^{7}$, and that the number of births in West Germany remains remarkably consistent throughout. The exact timing of the onset of the fall in births numbers in the East is very interesting since it occurs exactly nine months after the fall of the Berlin Wall; i.e. by August 1990. This is a first piece of evidence that the collapse of the regime was not foreseen and that the drop is not driven by immediate use of abortion. As such; it was a change in the decisions to conceive that drove the reduction in fertility. Note also that the drop

\footnotetext{
${ }^{7}$ Since birth rate in the Eastern Länder started dropping from August 1990 onwards, the 1990 cohort can be considered partially treated. However, in the absence of data on month of birth we cannot use the discontinuity. Similarly, the 1994 cohort can be considered partially treated. We therefore also consider whether our main results are robust to slight changes to the definition of the 'Children of the Wall'.
} 
in births in the East is not solely due to displacement of mothers-to-be to the West, since the numbers of births in the West remains on trend.

[Figure 3 about here]

\subsection{Explaining the Fertility Drop}

We consider three potential reasons why fertility fell so sharply in East Germany after the fall of the Berlin Wall: change in birth control provision, East to West migration, and economic uncertainty. Although it is difficult to exactly measure the relative importance of these factors, we provide evidence here that the decrease in the number of births was mostly driven by economic considerations. The issue of whether women postponed, reduced their family size or whether more women remained childless is of interest but outside the scope of this paper, since our aim is to understand changes to the composition of the cohort of children born between 1991 and $1993^{8}$.

\subsubsection{Access to birth control methods}

Most of the previous literature on fertility decisions and child outcomes has exploited policies which changed access to birth control, predominantly access to abortion. Here instead, we argue that access to birth control is unlikely to be an important factor in the sudden drop in the number of births ${ }^{9}$. First, access to birth control methods was very liberal in East Germany and the right to on-demand abortion was not modified before 1993, after which

\footnotetext{
${ }^{8}$ As these delayed fertility issues could have changed the composition of individuals born after 1993, we will consider the robustness of our results to specifications which exclude these post treatment cohorts.

${ }^{9}$ Note also that the cohort of women coming to their peak fertility age after 1989 was relatively smaller - born during the fertility ebb of the early Seventies. This natural cohort size effect contributes to at the most 10 percent of the drop in the number of birth observed (Eberstadt [1994]).
} 
it became more restricted ${ }^{10}$. Second, one could have expected that faced with the immediate uncertainty of a new environment, potential mothers would have terminated pregnancies in greater numbers. We have already argued that the exact timing of the fertility drop (Figure 3) does not appear to support this idea in the very short run. Additionally, the number of terminations in the five East German Länder (excluding Berlin) dropped from 72,774 in 1988 to 26,207 in 1994 (-63 percent). This more than matches the drop in the number of births observed over this period (-57 percent) which translates into a small decrease in the abortion to birth ratio. We can thus safely say that the fall in fertility is mostly due to a fall in conceptions. This is important for two reasons. First, it implies that our 'pre-treatment' groups (of mothers and children) are not selected post-conception. Second, we can assume that the children eventually born must have been 'wanted' by their mothers at the time, which makes it a very different selection mechanism than when a drop in fertility is driven by the legalization of abortion, and the fewer 'unwanted' children in a cohort it implies.

\subsubsection{Internal migration}

One of the most important changes in the life of East Germans after the fall of the Berlin Wall was that direct migration to the more opulent West became possible again. A substantial number of individuals made use of this newfound freedom with almost 800,000 individuals migrating from East to West, representing 5 percent of the pre-1991 population. This internal migration flow quickly died down, and by 1993 almost as many Germans were making the move in the opposite direction. Hunt (2006) demonstrates that improvements in relative wages were responsible for the ebbing of eastern migration. Movers were on average younger and more likely to be female (Fuchs-Schündeln and Schündeln [2009]), and thus internal migration did have an impact on the reduction in the number of births in the East.

\footnotetext{
${ }^{10}$ Sterilization became then available, however this contraception method was used by less than three percent of women (Rheinheckel et al [1998]).
} 
Eberstadt (1994) estimates that internal migration accounted for about 10 percent of the total drop in birth numbers. This however does not really put in doubt the magnitude of the fertility drop since the crude birth rate used to illustrate it in Figures 1 and 2 uses number of women in the population as a denominator.

Migration remains a worry for the validity of our identification, even if it does not directly explain the drop in fertility, since it could still distort the composition of the cohorts of individuals we observe in West Germany. This would be the case if mothers of young children migrated in substantial numbers or if many of the women who moved to the West

subsequently gave birth there, but this is not observed in the raw data presented as West Germany birth numbers remain on trend. Our main crime outcome, arrest rate, is measured at the cohort level by state and could remain affected by the distorting effect of current or future mothers migrating. In a subsequent robustness check, we account for the fraction of women of childbearing age who have moved out of the state. Note, for our micro-level analysis, western migration is not an issue since we allocate the treatment status based on place of residence of the mother in 1989.

\subsubsection{Economic Uncertainty}

During the half-century of communist rule, there was no uncertainty concerning employment and wages, and women were very integrated into the labor force. The costs of having children were kept low due to the public provision of childcare, health and educational services. In the months immediately following the fall of the Berlin Wall, full employment policies were abandoned, and by the end of 1994 almost a third of the pre-unification jobs had been eliminated and 65 percent of those unemployed were women. The generous and universal benefits linked to having a child were quickly curtailed to match Western levels, while the availability of childcare shrank and housing costs surged (Rheinheckel et al. [1998]). 
This negative economic picture was mitigated by the aforementioned rapid catch up of Eastern wages, which were negotiated to reach parity with the West by 1994, large financial transfers from the West, and a generous one to one conversion of the OstMark to the DeutscheMark in July 1990. In fact, by some measures individuals in the new Länder were economically 'better off' with disposable income and consumption on average already higher just three years after the fall of the Wall (Dornbusch and Wolf [1992]). Considering this, can we still argue that it is economic uncertainty that explains the drastic fall in the number of children being born? We believe so for two reasons.

[Figure 4 about here]

First, the economic situation and the associated uncertainties are likely to be important determinant of the timing of fertility decisions. The 1992 Population Policy Acceptance Study (PPAS) allows us to link the perception of economic uncertainty to fertility decisions ${ }^{11}$. When asked in this survey what were the reasons for not wanting a(nother) child, the most common reason given by 78 percent of East Germans was poor economic circumstances. The next two most common answers were also related to the perception of the economic situation: costs of raising children (60 percent) and fear of the future (49 percent). Additionally, the GSOEP allow us to track the evolution of the perception of economic situation and childcare provision over time. Figure 4 reports the difference between East and West Germany in the fraction of individuals worried about the economic situation. Following reunification, East Germans are 20 percentage points more likely to be very worried about the economy. This difference increases up to 30 percentage points in 1991 - before the views on the economy converged by 1993 and remain close thereafter. Amazingly, this is precisely when we start observing a rebound in birth rates in the East, which is consistent with our assumption that economic uncertainty was one of the main factors behind the drop in fertility in the east. Additionally, in 1991 $45 \%$ of East German workers asked about their probability of losing their jobs within the next 12

\footnotetext{
${ }^{11}$ The Population Policy Acceptance Study (PPAS) is a comparative survey of European attitudes and opinions concerning demographic changes, demographic behaviours and population related policies. In Germany, the first survey was conducted in 1992. About 10,000 men and women in East and West Germany between the ages of 20 and 39 years were asked about family policy, its impact and expectations on future family policies. For more on this survey see: http://www.bib-demografie.de/EN/Research/Surveys/PPAS/ppas node.html
} 
months reported that they would definitely or probably lose it. This probability is only $5 \%$ in West Germany. For East Germans, this perceived probability of job lost felt to 21\% and 16\% by 1993 and 1996 respectively; while still higher than in the West, which remains around $8 \%$ in that period, this shows a remarkable convergence of perceptions within the three years following re-unification.

Since the PPAS indicates that childcare was also an important concern, we also assess with the GSOEP the differences in the perception of childcare availability between East and West over time. Again we observe that East German parents are more worried about childcare but that they converge towards the West perception rapidly. These measures thus validate the definition of the CoW since by 1993, the expectations about the economy and childcare of both East and West Germans have broadly converged.

Second, what principally interests us is which women adjusted their fertility decision to this economic uncertainty. As such, the cohort composition is determined by the relative sizes of the income and substitution effects for different sub-groups. Perry (2004) argues that the income effect dominates for high wage earners while the substitution effect dominates for low wage earners. The former should therefore be more likely to stop having children during a recession while the latter will increase their fertility during bad economic times; as such the cohort composition/quality is procyclical. The massive fertility drop we study should have, following this logic, been mostly driven by women of higher socio-economic status deciding not to give birth as a response to economic uncertainty. We will later provide some empirical evidence supporting this heterogeneity in the response to economic uncertainty Consequently, relatively less well-off and less educated women became much more represented as mothers of these smaller cohorts. With this theoretical framework we can predict that the 'Children of the Wall' were the result of negative maternal selection as a response to high economic uncertainty.

We next empirically test this assumption and try to understand the selection mechanism.

\section{Data Sources and Empirical Strategy}




\subsection{The Data}

\subsubsection{State Level Data}

We obtained administrative crime data at the Land level on an annual basis from the Federal Criminal Police Office (BKA) ${ }^{12}$. Since our identification strategy relies on following the criminal activity of a specific cohort, we need information on the age of offenders. We thus use data on number of arrests by gender and per crime category ${ }^{13}$ from 1993 to 2011 for 5 Eastern and 10 Western Länder (we exclude Berlin, the only state which straddles the old East/West border). This information is not available by discrete ages but only for the following - mostly two year - age groups: $0-5,6-7,8-9,10-11,12-13,14-15,16-17,18-20$, 21-22, 23-24, 25-29, 30-39, 40-49, 50-59, 60+ ${ }^{14}$. This slightly complicates our definition of 'Children of the Wall' cohorts for the analysis as the CoW straddle age groups. For each period, we therefore compute an indicator of the proportion of each group that is treated. This indicator is 0 when the CoW is either too young or too old for the age group of interest. Since most of the age groups include two birth cohorts, we mostly have that for a given age group, half the individuals are treated when the CoW cohorts enters it, the full age group is considered treated the following two years, and half again three years later, as the CoW cohorts exit it. The values this indicator takes across years for the different age groups are reported in Table 1. This indicator is a simple weight of the proportion of an age group considered treated in each year ${ }^{15}$. The BKA also provided us with the number of active police

\footnotetext{
${ }^{12}$ We are grateful to Daniel Focke from the Bundeskriminalamt (www.bka.de) for providing us with this data.

${ }^{13}$ We follow the standard BKA classification the 2010 Police Crime Statistics Yearbook - List of Offences (http://www.bka.de/nn_195196/SharedDocs/Downloads/EN/Publications/PoliceCrimeStatistics/pks2010ListOfO ffenses,templateId=raw,property=publicationFile.pdf/pks2010ListOfOffenses.pdf) to aggregate the more than 400 sub-categories into five broad crime groups which together represent 85 percent of all arrests: violent and sexual; thefts and burglaries, fraud and forgery, criminal damage, and drug offences.

${ }^{14}$ Before the age of 14, the data refers to recorded incidents of 'contact with the police' rather than arrest which are not legal before this age in Germany

${ }^{15}$ These proportions do not take into account that the CoW cohorts were smaller and thus are likely to underestimate the treatment effect, nor that criminal propensity differs by age, within an age group. To solve this problem, we weight all regressions by Land/year age-group population. Note also that a Breutsch-Pagan test detected heteroscedasticity in the residuals of the un-weighted regression, the procedure recommended by Solon, Haider, and Wooldridge (2013) to empirically justify the use of group sample size weights to improve the precision of estimation.
} 
personnel by year and Land for this period which, if changing, may affect the probability of arrest.

[Table 1 about here]

We gathered a number of other important variables from the Federal Statistics Office to complete our State level panel dataset: population size by age, gender and nationality (to create our cohort size denominator and control for the influence that foreign migration could have on crime); and the overall and youth unemployment rates (to control for local economic conditions). Altogether the panel dataset we generate covers 15 age groups in 15 Länder over 19 years and as such is made up of 4,275 age-state-year cells.

\subsubsection{Individual Level Data: The GSOEP}

The German Socioeconomic Panel (GSOEP) is a large longitudinal survey, carried out annually, of private households first established in West Germany in 1984. Since 1990, it also includes individuals from former East German Länder. We thus use data from 1990 to 2011 comprising of more than 50,000 unique individuals, a quarter of whom lived in the East. The GSOEP includes detailed personal characteristics and extensive questionnaires for all members of the households, including retrospective information when necessary. The main survey is augmented by topic specific modules, and we make extensive use of the ones with survey questions focusing on mothers, young adult (aged 17), and risk preferences. The GSOEP unfortunately does not contain a single question on self-reported criminal participation $^{16}$.

\footnotetext{
${ }^{16}$ More information on the GSOEP is available at http://panel.gsoep.de/
} 


\subsection{Empirical Strategy}

For all outcomes our empirical strategy relies on a differences in differences approach which exploits the natural experiment provided by the post-Berlin Wall drop in birth rates. We compare the characteristics or outcomes of children who were born in East Germany in 1991, 1992, and 1993, or of their mothers, to individuals born before 1991 (and after 1994 in a few cases). The counterfactual, or second difference, is provided by the non-treated individuals (or cohorts) from West German Länder which enable us to naturally control for common macro shocks and time trends. A necessary condition for this differences in differences identification approach to be valid is that the common trend hypothesis holds. We later carefully check that it does, providing graphical and econometric evidence. However, because of the nature and structure of our individual and cohort level data, we must define two different modeling strategies that depict our general differences in differences approach.

\subsubsection{Cohort Level Analysis - Crime}

As mentioned previously, the arrest data at the Land level is only available by year age-groups, and we compute an indicator of the fraction of the age group that is treated. Once interacted with being an Eastern Land, this becomes the main explanatory variable in our analysis which captures the proportion of 'Children of the Wall' in each cohort. PropCoW ast, the subscripts $a$, $s$ and $t$ refer to respectively the age group, the Land, and the year.

Our main outcome for measuring criminal participation is the arrest per 1,000 inhabitants in the age group: $Y_{\text {ast }}$ defined as:

$$
Y_{a s t}=\ln \left(A_{a s t} / \frac{N_{a s t}}{1000}\right)
$$

where the numerator $\mathrm{A}$ is the number of arrestees, and the denominator $\mathrm{N}$ is the relevant population size. We then take the natural logarithm of this fraction to be able to later interpret 
the estimated coefficient on $Y_{a s t}$ as the elasticity in the arrest rate per 1,000 population of the age-group $(a)$ in a Land $(s)$ at time $(t)$. This is first generated for all individuals and all arrests types but also separately by gender and for five distinct crime categories.

We run various specifications of the basic model (1) to obtain the differences-indifferences estimates of the criminal propensity of the 'Children of the Wall':

$$
Y_{\text {ast }}=\beta \text { PropCoW ast }+\delta Z_{\text {st }}+\gamma Y r_{t}+\rho A g e_{a}+\alpha_{s}+\varepsilon_{a s t}
$$

PropCoW is, as explained above, an interaction between an ex-GDR Länder indicator and the proportion in a specific age-group cohort that are born in 1991-1993. Age, $Y r$, and $\alpha_{s}$ are sets of dummies for age-group, year and Land respectively. We also include $Z$ which is a set of time varying Land specific controls to account for local factors which may impact on criminal participation. These are specifically: overall and youth unemployment, proportion of foreign born per age group, and number of police personnel per 10,000 inhabitants. Each cell is weighted by the population size of the age-group, in the state for the year, and standard errors are then clustered at the Land level.

We conduct various robustness checks of estimates from this basic specification. to account for potential state specific unobservable characteristics (i.e. we relax the assumption of common trends between state and instead use Land specific linear time trends), ii) variations in the definition of the cohorts of interest and iii) assess the impact of internal migration. For the latter, we obtained yearly Land to Land population movement data by gender and age ${ }^{17} i$ ) we generated an indicator of 'potential mothers migration' which is the net number of women of reproductive age which moved out of state relative to its population

\footnotetext{
${ }^{17}$ We are very indebted to the Federal Statistics Office (www.destatis.de) for providing us with this administrative dataset. Unfortunately this information only starts in 1991 for the Easter Länder which is admittedly just after the largest outflow had taken place. We still think that we can accurately capture which were the relatively highest sender and receiver Länder from this internal migration using this data.
} 
relative to the number of women in the local population iii) include this variable as a control in our preferred crime specifications.

\subsubsection{Individual Level Analysis - Parental Selection and Children Non-Crime Outcomes}

To assess parental selection into motherhood and investigate children’s non-crime outcomes, we rely on individual level data from the GSOEP. For all these outcomes, we obtain estimates of $\beta$ from slightly varying specifications of the following basic differencesin-differences model:

$$
Y_{i}=\alpha+\beta \operatorname{CoW}_{i}+\gamma \text { East }_{i}+\delta B 91_{-} 3_{i}+\theta Y o B_{i}+\rho X_{i}+\varepsilon_{i}
$$

CoW is a dummy for 'Children of the Wall' which is 1 if gave birth (or born) in the East between 1991 and 1993 and 0 otherwise. East is a dummy for being in East Germany at birth or in 1991, B91_3 is a dummy for being born (having given birth) between 1991 and 1993, and $Y o B$ is a quadratic term of the year of birth to account for potential cohort effects. $X$ is a vector of individual level characteristics which include, depending on the specification, for mothers: number of children, age, and years of education. For children the characteristics included are, depending on the model estimated: gender, number of siblings, years living in single mother household, and years of education. $\varepsilon_{i}$ is an error term assumed to be independent and normally distributed across individuals $i$. All regressions are weighted by cohort size to account for the large changes in cohort sizes during the period and standard errors are always clustered by state ${ }^{18}$.

\footnotetext{
${ }^{18}$ Clustering is a crucial issue here since the results from Donohue and Levitt (2001) were criticized by Joyce (2004) and Foote and Goetz (2008) for only being significant because of artificially low standard errors as a result of inappropriately clustering at the state*cohort level rather than just state. The argument is that a wider cluster better account better for potential correlation between cohorts and Foote and Goetz (2008) indeed show that using state only generates much larger standard errors. Here we tried both State and State*year of birth (as well as East*year of birth) as clusters. The former was constantly giving us larger standard errors indicating that
} 


\section{Criminal Participation of the 'Children of the Wall'}

\subsection{Graphical Illustration}

Before turning to our statistical analysis, we illustrate graphically the evolution of criminal participation from 1993 to 2011 in East and West Germany using arrest rates for three distinctive age-groups. Figures 4 reports the arrest rates for individuals aged 6 to 7 (top graph), aged 10 to 11 (middle graph) and aged 16 to 17 (bottom graph). The plain/dotted lines are for East/West Germany, respectively and the vertical lines mark the year of arrival and departure of the 'Children of the Wall' cohorts from each specific age-group. As such they denote the period during which the proportion of cohort treated, as reported in Table 1 , is positive.

[Figure 5 about here]

Overall, all graphs in Figure 5 indicate that youth arrest rates are almost always higher in East German Länder than in Western ones. This is well documented and perhaps not surprising considering the important differences in relative economic deprivation between the two parts of the country. It is however not a problem for our identification approach here since it is easy to account for this baseline crime gap by including Land specific fixed effects. What is crucial is that we have relatively similar trends in arrests between East and West Germany when the treated cohorts are not present, consistent with the common trend hypothesis. In that respect, the figures are quite striking and all reveal very marked 'peaks' in the arrest rate of East German cohorts when the cohorts born between 1991 and 1993 enter an 
age group; such peaks are not observed in West Germany. Otherwise, the arrest rates in both regions follow similar paths. This pattern becomes increasingly pronounced as the cohorts become older and much larger arrest rates per population improve the precision of the graphs $^{19}$

Figure 5 therefore clearly illustrates three things. First, that the criminal propensity of the 'Children of the Wall' appears much higher than that of cohorts born before, a phenomena that we do not observe for their Western peers. Second, the lines depicting arrest rates of the pre-treatment cohorts in each age group in both regions are mostly parallel, especially for older age groups as arrest becomes more common, indicating that the common trend hypothesis is met. We indeed find that this is statistically the case when we test for the significance of a coefficient on differences in pre-trends which is small and non-significant ${ }^{20}$. Third, the increase in arrest observed for the CoW cohort is unlikely to be driven by unobserved time effects like changes in policing activity, since the effect is observed at different dates for the different age groups but always when the fraction of CoW in an age group is positive.

\subsection{Statistical Results}

\subsubsection{Baseline Crime Results}

We now move to our econometric analysis and Table 2 reports results from estimating various specifications of equation (1). The coefficients represent the elasticities of arrest rate to the fraction of 'Children of the Wall' in the cohort. They are presented to include sequentially: only age group, Land, and year dummies in column (1); time varying state controls in column (2); and Land specific time trends in column (3). Finally, the results are

\footnotetext{
${ }^{19}$ Graphs for the other age groups reveal the same patterns and are available upon request

${ }^{20}$ We do this by regressing an interaction of East and being born before 1991 on arrest rates and this gives us a coefficient of -0.004 with an associated standard error of 0.007 .
} 
reported alternatively for all age groups in row (i) and only for individuals under 21s in row (ii), as older adults may not be a good control for youth offending behavior; indeed since peak criminal activity increases sharply up to age 19 and decreases thereafter, including older adults would likely over-estimate the effect. The estimated coefficients are all large, very significant, and not significantly different from one another across specifications (when using the same sample of individuals). These results confirm that the 'Children of the Wall' engaged disproportionally more in criminal activity and that this is equally true for men and women. Looking at the most conservative estimates, the fullest specifications for under $21 \mathrm{~s}$ only (i.e. column (3) of row (ii)), we can conclude that the 'Children of the Wall' are 42.5 percent more likely to participate in criminal activity than their older/younger and Western peers. Surprisingly, the effect is also remarkably similar for both men and women, the later, a group for which criminality has been under-studied because their relatively low participation rate. The high criminality of the CoW indicates that as expected, this cohort is negatively selected, and despite its small size, commits a disproportionally high amount of crime.

[Table 2 about here]

\subsubsection{Results by Crime Category and Gender}

In Table 3 we report the results for our preferred specification, by crime category for all individuals under 21 in row (i), for men in row (ii), and women in row (iii). The numbers in square brackets are the average arrest rates per 1,000 population of under 21 s for each crime type. We note that most arrests are for three crime categories (theft and burglary, violent and sexual, and criminal damage), with the first category alone representing almost 50 percent of arrests. Men are on average arrested much more than women (three times more for 
theft and burglary and nine times more for Criminal Damage). The estimated coefficients of the effect of being born as part of the CoW cohort are large and quite precisely estimated for all crimes except for drug offences. The effect is not statistically different between each crime category, reflecting that all arrests are similarly affected by the CoW cohorts, which is comforting as this suggests that our results are not driven by a specific crime which may have been targeted by the police force and that the CoW cohort would have been disproportionally engaged in. Interestingly, these estimates are again very similar for women and men. Since women commit a small fraction of crimes this again confirms that our results are unlikely to be driven by police force strategies specifically targeting the CoW cohort. These results further confirm that the 'Children of the Wall’ have very unusually high probability of being arrested and that this is true for most crime categories and across genders.

[Table 3 about here]

\subsubsection{Robustness of Crime Results}

Before we investigate the mechanisms behind this sharp rise in arrest for the CoW cohort, we report in Table 4 the results from a series of robustness checks based on our favored specification. First, in row 1, to account for internal migration, we include for each year and age group a measure of the net proportion of potential mothers who moved from Land to Land. Once included in our preferred specification, we find that, while significant by itself, migration only very marginally affects our estimate: $0.423(0.078)$ when included compared to $0.425(0.075)$ before. This is relatively strong evidence that internal migration is not the driving mechanism behind our results. 
[Table 4 about here]

In the next specification, row 2, we eliminate the few cohorts born after 1993, from the analysis, as these could be considered treated, since if better parents postponed their fertility decisions between 1991 and 1993, they may catch-up when the uncertainty is reduced, and subsequent cohorts would be positively selected. Indeed, excluding those increases the estimated elasticity to 0.596 (0.148). In rows 3 and 4 , we further tighten the window of cohorts used as controls and only keep those born at most six and three years before the CoW respectively. This is akin to framing our estimates into a discontinuity design to ensure that treated and control individuals are as similar as possible which entails here that they mostly faced the same environment when growing up in reunified Germany. The resulting estimates are larger and significant and for the smaller window we find that 'Children of the Wall' have on average a 50 percent higher arrest rates than individuals born just three years before.

The next two rows of Table 4 report estimates when we alter the definition of CoW. As explained above, children born from August 1990 were conceived after the collapse of the Wall and as such the 1990 cohort is partially treated. When we consider all children born in 1990 in the East as also treated individuals (row 5), the estimate shrinks to 0.342 (0.058), due to measurement error in the treatment variable, but this is not statistically different from the baseline estimate. In row 6, we expand the definition of CoW to include children born in 1994, as the rebound in birth number started in that year, this brings us back almost exactly to our original estimate.

Finally, in the final specification of Table 4, we present a placebo test where we assume that the treated cohorts were those born between 1987 and 1989 and drop all the 
subsequent cohorts. If the environment young children were exposed to after the collapse of the Berlin Wall had an effect on crime, we should find some effect on arrest later in life for these cohorts born just before the collapse of the communist regime. We reject this assumption as the placebo estimate is not statistically significant and with a coefficient eight times smaller than in our baseline estimate. All these robustness check are very reassuring as to the validity of our results and we now consider them in perspective to previous findings in this literature.

\subsubsection{Our Crime Results in Perspective}

Our results confirm the Donohue and Levitt (2001) hypothesis that fertility decisions can have a large effect on the subsequent criminal activity of children. We find that the cohorts of children born in East Germany between 1991 and 1993 commit a much greater fraction of crime than would be expected, which is consistent with the interpretation of negative parental selection. This is despite being part of much smaller cohorts, which in theory should have a positive effect on outcomes (e.g., via smaller class sizes and lower competition on the labor market). Legalization of abortion in the U.S. resulted in fewer children being born from mothers with relatively worse parental characteristics, as such it was impossible to distinguish the potential positive effect on child outcomes of smaller cohort size from the effect of positive selection into fertility. Those estimates were thus over-estimates of the parental selection effect. The bias may indeed be large, and for Romania, Pop-Eleches (2006) estimated that $50 \%$ of the effect of abortion may be due to cohort size ${ }^{21}$. Here, we are unable to separate the cohort size from parental selection effects but since the two effects

\footnotetext{
${ }^{21}$ The Romanian abortion ban studied by Pop-Eleches (2006) resulted in larger cohorts of positively selected children and could have naturally led to underestimates of the fertility selection effect. The author however prefers to control for socio-economic composition of mothers to show that the ban led to worse outcomes for children. He therefore shows that the larger cohort size effect (or crowding out effect as it is called in this paper) goes in the same direction as the treatment effect and therefore attempts to measure its importance.
} 
operate in opposite directions, we can argue that, our estimates on criminal activity presented above represent a lower bound of the true impact of fertility selection on the offending behavior of the child generation.

Our most conservative estimates state that the arrest rate of this cohort is 40 percent higher than expected. These are large effects but they are actually consistent with Donohue and Levitt (2001, 2004, 2009) who concluded that the legalization of abortion was responsible for 50 percent of the drop in crime observed in the U.S. in the $1990 \mathrm{~s}^{22}$. Our results do not however entail that overall crime will increase in East Germany. First, the 'Children of the Wall' reached the peak offending age of 19-20 (in 2010-2013), and second, they represent a small fraction of the total number of arrests, being only three birth-year cohorts and being 50 percent smaller than usual birth year cohorts. However, as the increase in arrest almost matches the reduction in cohort size, we expect that overall crime will 'not fall' much . Despite the small size of the CoW cohort, the overall arrest rates felt only from 8.6 in 2005 to 7.7 in 2011 in East Germany, the latest year for which data is available. Since it did not lead to the same aggregate changes in crime as in the US, the very high propensity of the 'Children of the Wall' to commit offences has until now remained unnoticed and has yet to enter the policy debate. This does not change the value of our findings which are perhaps the most robust evidence to date that parental selection has a very strong effect on child offending behaviour.

In the next section we turn to micro level data to document the negative selection process and to explore a number of underlying mechanisms that may explain why the 'Children of the Wall' are so prone to committing crimes,

\footnotetext{
${ }^{22}$ Since the country, the identification and the population affected are different, the similarity with the U.S. results was rather unexpected.
} 


\section{The Fertility-Crime Relationship: Mechanisms}

\subsection{Parental Selection}

As already discussed, the large fertility drop we study is certainly not random across women and is likely to be driven by parental selection. Our prior, after reviewing the evidence on the criminal activity of the 'Children of the Wall', is that they were the product of important negative selection into motherhood. Faced with a high level of uncertainty about the future and a new set of (unknown) constraints regarding the costs of child rearing, women with relatively lower parenting skills were relatively more likely to conceive and give birth in the years following the collapse of the Communist regime.

To test this hypothesis we now turn to the GSOEP data and focus on the sub-sample of women who gave birth in East or West Germany between 1980 and 2000. Note that the GSOEP provides retrospective information on location in 1990, which we use to allocate the CoW status so that these estimates are not affected by subsequent migration decisions. We begin by using equation (2) to compare the mothers of the 'Children of the Wall' on a number of 'positive' socio-economic characteristics to those of other mothers, and report the results in Table 5. First, we note that East German mothers over this period are on average quite different to their Western peers; this is captured by the strongly significant coefficients on the 'Birth East' dummy. Additionally, the mothers of CoW are on average over 10 months younger, have almost one year less of education, and are 11 percentage points less likely to have completed high school. At the time of survey completion, they were also respectively 9 and 12 percentage points less likely to be in a stable relationship or economically active. These results clearly indicate that our prior was correct and women who had children during the very uncertain times following the fall of the Berlin Wall were negatively selected on all 
the standard socio-economic characteristics which are associated with relatively lower parental skills.

[Table 5 about here]

Negative parental selection of the 'Children of the Wall' cohorts is very apparent, but can it be linked to economic uncertainty in this period as we argued? To do this, we consider whether there is heterogeneity by education in women's fertility response to the negative perception of the economic situation. Practically, we regress the probability of having a child in the period 1991/93, for all women aged 17 to 47 interviewed in the GSOEP , on a measure of economic uncertainty in year $t-1$ (i.e. dummy for being 'very worried' about 'the general economic development' ${ }^{23}$. We find that uncertainty is negatively related to fertility, as might have been expected. We then include an interaction of years of education and economic uncertainty in the probability model we estimate. This interaction is negative and significant. Figure 6, reports the estimated probability of giving birth and the associated confidence interval, by education level and level of worry about the economy. More worried women (solid line) and more educated women are less likely to give birth. What Figure 6 clearly shows is that the fertility decision of less educated women is not significantly affected by economic uncertainty. On the contrary, highly educated women’s fertility drops when worried about the economy. For the most educated, very worried women are 2.5 times less likely to have a child than less worried one.. This evidence reinforces our argument that the parental selection we have documented works through economic uncertainty perception as the fertility

\footnotetext{
${ }^{23}$ The model also includes education, age and year dummies and the standard errors are clustered at East level to account for important common age shocks on fertility which are likely to be different between East and West Germany.
} 
of mothers with disproportionally unfavorable characteristics is less responsive to socioeconomic shocks.

[Figure 6 about here]

\subsection{Children’s Criminal Behaviour: School or Parents?}

While the cohort level evidence has strongly shown that the 'Children of the Wall' are much more likely to be arrested, we now explore whether they also differ on other observable non-crime outcomes; to assess whether those would also be consistent with negative parental selection. We do this by using GSOEP information collected when individuals are aged $17^{24}$ and implementing the model described in equation (2). The education variables reported in Table 6 are somewhat limited since at age 17 German pupils are mostly all enrolled in education; as such it is unsurprising that there is no difference in the probability of CoW of being a school drop-out. They are however five percentage points more likely to have repeated a grade by that age, and almost a quarter of them self-report below average scores in math and German. Overall, the difference in educational attainment is suggestive that the 'Children of the Wall' also have negative outcomes in other dimensions but not as strong as the arrest evidence. A first explanation is that these youths are still too young and that achievement gaps may only become clear once they leave education at age 18 . The repeater and test score result suggest this is likely to happen. Secondly, small cohort size effects (i.e.

\footnotetext{
${ }^{24}$ The last GSOEP survey available is from 2011 which means that the last individuals who completed this special module were born in 1994. Consequently we only have one cohort in our control group which is born after the fertility shock subsided.
} 
smaller classes) may have had a positive impact on educational attainment and could have partially compensated for the poorer parental input ${ }^{25}$.

While the rest of the literature has relied on the socio-economic characteristics of mothers to argue for the parental selection mechanism, we investigate this issue more directly, and arguably more objectively, by relying on information on parental skills and maternal relationship. The GSOEP provides a unique opportunity to test the quality of parental skills with a survey supplement at age 17 containing a battery of questions about emotional perception, such as listing people who have been important persons in the child's life ${ }^{26}$. The last three columns of Table 6 report the evidence on maternal relationship. On average, 94 percent of the sample reports that their mother has been an important figure throughout their life, but children born in East Germany just after the fall of the Berlin Wall are 11 percentage points less likely to make this statement. Another strong indicator of maternal attachment is whether these teenagers feel loved by their mothers ${ }^{27}$. Our estimate suggests that the CoW are 14 percentage points less likely to be in this category suggesting much lower lever of maternal attachment. Finally, we use an overall measure of 'supportive parenting' that is a multi-item scale of nine questions ${ }^{28}$ to gauge parental participation in a child's life and how much the parent involves the child in decision making. This exercise reveals that the 'Children of the Wall' are almost 30 percentage points less likely to say that they have supportive mothers. While it is possible that the criminal activity of the children has reduced the maternal involvement in their upbringing, we later provide evidence infirming this hypotheses, and thus supporting a causal interpretation of these results.

\footnotetext{
${ }^{25}$ Kempkes (2010) suggests that while resources decreased with cohort size in East Germany over the period 1993 to 2006, the teacher/student ratio improved by 25\%.

${ }^{26}$ The original question is a 4-points scale answer which we dichotomize by grouping 'important' and 'very important' categories and the 'less important' and 'not important at all' ones together.

${ }^{27}$ They are asked if their "Mother Shows that she Loves you" and have five possible answers going from 'very often' (45 percent) to 'never' (1 percent). We generate a dummy variable which is one if the youths respond 'very often' and zero otherwise.

${ }^{28}$ The original conceptualization of this measure of supportive parenting was proposed by Simons et al (1992) and its application to the GSOEP is described in Weinhardt and Schupp (2011)
} 
[Table 6 about here]

These results generally hint to the important role potentially played by a poor maternal relationship in explaining the abnormal levels of criminal participation observed. This is perhaps not surprising as low level of parental support or even parental rejection have been associated to higher level of delinquency (see Hoeve et al. [2009] and references therein). What is interesting is to note that we might have assumed that women who chose to give birth during very uncertain economic times might have really wanted a child. Otherwise, they could have made use of abortion, a birth control widely available at the time, to avoid that an 'unwanted' conception led to a birth. These initially 'wanted' children later have poor relationships with their mother, which may account for why they commit many more offences. However, we still need to understand why these mothers chose to have these children at that time.

\subsection{Intergenerational Risk Attitude}

An important dimension that could link parental fertility decision and criminal activity of children, which surprisingly has not been previously mentioned in the literature, is risk attitude. A preference for risky behavior has long been associated with most unsafe youth activities (Gruber [2001]), and recent literature has pointed out the importance of risk attitude in predicting many individual economic outcomes (Dohmen et al [2011]). We therefore exploit the very detailed risk attitude information contained in the GSOEP to test if this plays an important role in the fertility-crime relationship. We obtain estimates on various measures of risk attitude, using models presented in (2), for both mothers and children, and the results are presented in Table 7. 
[Table 7 about here]

Mothers who gave birth in East Germany just after the fall of the Berlin Wall have a greater preference for risk. Both for overall risk Level (willingness to take risk in life rated from 0 to 10) and Risk Lover (risk level above 5) we obtain strongly positive and significant coefficient for these women, even after controlling for age and education ${ }^{29}$. Overall risk attitude can have positive or negative consequences for economic outcomes as, for example, entrepreneurs are on average more risk lover individuals. To address this, we propose to use the questionnaire of activity specific risk which make it possible to clearly differentiate between potential 'bad' and 'good' risky behavior' ${ }^{30}$ 'Bad' risk is defined from answers to the willingness to take risk with own health and while driving. 'Good' risk is measured as the willingness to take financial risk. The results are here striking as it emerges that it is only with regards to taking more 'bad risk', and not 'good risk', that the mothers of CoW significantly differ from their peers.

Turning to the 'Children of the Wall' themselves in the last three columns of Table 7, we find that on all measures (level and lover) they are more willing to take risk than their older/Western peers ${ }^{31}$. This might have been expected as criminal behavior could be considered to be the risky behavior outcome par excellence. These findings also indirectly confirm what Dohmen et al. (2012) have recently shown: that parents transmit preferences for risk to their children. This transmission of risk preferences is an important mechanism of the

\footnotetext{
${ }^{29}$ We are actually not the first to report this link as Schmitt (2012) documented that individuals with higher levels of willingness were more likely to have had children in East Germany after the end of communism.

${ }^{30}$ This question was asked only twice and not recently enough (last year 2009) to have the equivalent data for children in the treated cohorts we are interested.

${ }^{31}$ An interesting side finding here also stems from the coefficient on the East dummy we report: significant for mothers but not for their children. It appears to confirm the assumption put forward by Alesina and FuchsSchündel (2007) of a convergence of preferences between East and West Germans within a generation as individual exposure to communism decreases.
} 
parental selection/criminal activity relationship that has until now been ignored. The women who gave birth at a time of great economic uncertainty were more risk takers, a trait they transmitted to their children, who then becomes more likely to engage in criminal activities. Moreover, these mothers had poor parental skills, so despite being wanted, these children are negatively selected.

\section{4 'Bad’ Mothers or ‘Bad’ Times? Sibling Evidence}

Finally despite the evidence of parental selection, the differences in the characteristics and behavior of the 'Children of the Wall' could also be consistent with the fetal programming (Barker [1995]) and early life adversity (Conti et al. [ 2012]) hypotheses. Aizer, Stroud, and Buka (2009), for example, show that maternal stress in utero has long term negative consequences for children, and that this effect is stronger for low socio-economic status mothers. Due to the high level of uncertainty faced by the mothers after the collapse of the Wall, these children would have experienced heightened levels of stress in the womb and in their very early years. This could have shaped their preferences and behaviour in a way to cope with such a world. As such, we could expect higher risk preference, lower emotional attachment and greater criminal probability; i.e. all our findings would no results from these children having had 'bad' parents but from being born in 'bad' economic times.

While our results that the mothers of CoW have worse observable and parental skills could be hard to reconcile with this theory alone, we carry out another test of the early life adversity hypothesis. To do so we identified all older siblings of individuals born between 1991 and 1993 in East Germany and estimate their maternal relationship and risk attitude as in equation (2). These older siblings could not have been "programmed" since they were born before the collapse of the Berlin Wall and, in the absence of negative parental selection, they 
should not report different outcomes to other children. Siblings are also informative for the causal interpretation of the evidence on the selection mechanism that we have presented so far. One could argue that the lower maternal involvement on the CoW is due to their criminal activity. However, since the older siblings of CoW are not more likely to engage in criminal activity, we should not expect that they report lower maternal involvement, unless they were also negatively selected.

[Table 8 about here]

Indeed, Table 8 reports that the older siblings of CoW have as poor maternal relationship as their younger siblings and are also more willing to take risk than their peers. This strongly supports that the observed effects for the CoW are due to negative parental selection and not to fetal programming, which we reject as the underlying mechanism behind our findings; i.e. the CoW cohort is disproportionally composed of children whose mother had higher preference for risk, lower parenting skills and lower observable characteristics associated with positive outcomes for the children.

\section{Conclusion}

This paper highlights the effects of parental selection on the subsequent criminal activity of children. While previous literature has relied on changes to the abortion laws as exogenous fertility shocks, we use the collapse of the Berlin Wall in 1989 which led to a 50 percent drop in fertility over a three years period in East Germany and a change in the composition of the cohort. We report that children born in East Germany in the aftermath of 
the regime change are at least 40 percent more likely to be arrested than those from previous cohorts. Since the fertility shock is local and temporary, we can exclude that the changes in arrest rate is not due to the parental selection associated with the fertility shock. Another advantage of our strategy is that since the cohort size and the parental selection effects go in opposite directions, our estimate of the parental selection effect is a lower bound. This large increase in criminality is consistent with either negative parental selection or some kind of cohort specific shock (maybe fetal programming). We find consistent evidence supporting negative parental selection, importantly we improve on the literature by demonstrating that mothers of CoW are more risk lovers and are rated as providing worse emotional attachment to their children. We also note that the older siblings of CoW also rate the emotional attachment of their parents poorly and also have a higher preference for risk, consistently with negative parental selection, but not with a cohort specific effect. To paraphrase Donohue and Levitt (2001), it is not so much that the 'Children of the Wall' were unwanted, but mostly that their mothers could not care enough.

Our findings on the large effects of parental selections have important implications for policy planners. Rather than base the decisions regarding public investment on cohort size only, there is scope for adjusting these investments for cohort quality. In this case, despite its small size, this cohort would have benefited from additional investment to compensate for the lower average quality of their parents. Strikingly, the rise in arrest for the CoW cohort starts as early as age 6 . As such, any interventions to compensate for the "bad" parental skills would have to be very early in childhood; consistent with the suggestions of Cunha and Heckman (2007) or Heckman et al (2010). Interventions when preferences are still malleable may break the intergenerational transmission of preferences, such as risk, which have an important role to play in criminal activity. However, identifying the children at risk is potentially difficult. While their mothers differ by some observable characteristics, they also largely differ along 
unobservable characteristics like risk preference and emotional attachment, which would make targeting challenging. Recent experimental evidence on the impact of home visiting programs aimed at risk mothers and their family which start even before the birth of the child, such as Preparing for Live in Dublin (Doyle et al [2013]) and Pro Kind in Germany (Sandner [2012]), are promising. The real challenge remains to find a way to target efficiently such interventions at the right mothers/children and, in that respect, we believe the findings from this research can be useful.

ROYAL HOLLOWAY, UNIVERSITY OF LONDON, CEE, ROA AND IZA

MAASTRICHT UNIVERSITY, CEP, ROA, AND CESIFO 


\section{References:}

Aizer, Anna, Laura Stroud, and Stephen Buka, "Maternal Stress and Child Outcomes: Evidence from Siblings”, NBER Working Paper No. w18422, 2009.

Alesina, Alberto, and Nicola Fuchs-Schündeln, “Goodbye Lenin (or Not?): The Effect of Communism on People’s Preferences,” American Economic Review, 97 (2007), 15071528.

Ananat, Elizabeth Oltmans, Jonathan Gruber, Phillip Levine, and Douglas Staiger “Abortion and Selection,” Review of Economics and Statistics, 91 (2009), 124-136.

Barker, David J.P., “Fetal Origins of Coronary Heart Disease,” British Medical Journal, 311 (1995), 171-174.

Bhaumik, Sumon Kumar, and Jeffery Nugent, "Real Options and Demographic Decision: Empirical Evidence from East and West Germany,” Applied Economics, 43 (2011), 2739-2749.

Burchardi, Konrad and Tarek Hassan, “The Economic Impact of Social Ties: Evidence from German Reunification,” Quarterly Journal of Economics, 128 (2013), 1219-1271.

Burstyn, Leonardo and Davide Cantoni, “A Tear in the Iron Curtain: The Impact of Western Television on Consumption Behavior,” CEPR Discussion Paper No 2012-19, 2012.

Charles, Kerwin Kofi, and Melvin Stephens, “Abortion legalization and Adolescent Substance use,” Journal of Law and Economics, 49 (2006), 481-505.

Conrad, Christof, Michael Lechner, and Welf Werner, “East German fertility after unification: crisis or adaptation?” Population and Development Review, 22 (1996), 331- 358.

Conti, Gabriella, Christopher Hansman, James J. Heckman, Matthew F. X. Novak, Angela Ruggiero, Stephen J. Suomi, "Primate Evidence on the Late Health Effects of Early 
Life Adversity,” Proceedings of the National Academy of Science, 109 (2012), 88668871.

Cook, Phillip, and John Laub, "After the Epidemic: Recent Trends in Youth Violence in the United States,” in Crime and Justice: A Review of Research, Michael Tonry ed. ( Chicago, IL: University of Chicago Press, 2002)

Cunha, Flavio, and James Heckman, “The Technology of Skill Formation," American Economic Review, 97 (2007), 31-47.

Dehejia, Rajeev, and Adriana Lleras-Muney, “Booms, Busts and Babies’ Health,” Quarterly Journal of Economics, 119 (2004), 1091-1130.

Dohmen, Thomas, Armin Falk, David Huffman, and Uwe Sunde, "The Intergenerational Transmission of Risk and Trust Attitudes,” Review of Economic Studies, 79 (2012), 645-677.

Dohmen, Thomas, Armin Falk, David Huffman, Uwe Sunde, Jürgen Schupp, and Gert G. Wagner, "Individual Risk Attitudes: Measurement, Determinants and Behavioral Consequences,” Journal of the European Economic Association, 9 (2011), 522-550.

Donohue, John J. III, Jeffrey Grogger, and Steven D. Levitt “The Impact of Legalized Abortion on Teen Childbearing”, American Law and Economics Review, 11 (2009), 24-46.

Donohue, John J. III, and Steven D. Levitt, "The impact of legalized abortion on crime," Quarterly Journal of Economics, 116 (2001), 379-420.

Donohue, John J. III, and Steven D. Levitt, "Further evidence that legalized Abortion Lowered Crime: A reply to Joyce,” Journal of Human Resources, 29 (2004), 29-49. 
Donohue, John J. III, and Steven D. Levitt, “Measurement Error, Legalized Abortion, and the Decline in Crime: A response to Foote and Goetz,” Quarterly Journal of Economics, 123 (2008), 425-440.

Dornbusch, Rudiger and Holger C. Wolf, “East German Economic Reconstruction,” in The Transition in Eastern Europe, Volume 1, Olivier Blanchard, Kenneth A. Froot, and Jeffrey D. Sachs ed. (Chicago IL: University of Chicago Press, 1992).

Doyle, Orla, Colm Harmon, James J. Heckman, Caitriona Logue, and Seong Moon, "Measuring the Investment in Human Capital Formation: An Experimental Analysis of Early Life Outcomes”, NBER Working Paper No. w19316, 2013.

Eberstadt, Nicholas, “Demographic Shocks After Communism: Eastern Germany 19891993,” Population and Development Review, 20 (1994), 137-152.

Foote, Christopher, and Christopher Goetz, “The Impact of Legalized Abortion on Crime: Comment,” Quarterly Journal of Economics, 123 (2008), 407-423.

Fuchs-Schündeln, Nicola, “The Response of Household Saving to the Large Shock of German Reunification,” American Economic Review, 98 (2008)., 1798-1828.

Fuchs-Schündeln, Nicola, and Matthias Schündeln, "Precautionary Savings and SelfSelection: Evidence for the German Reunification 'Experiment',” Quarterly Journal of Economics, 120 (2005), 1085-1120.

Fuchs-Schündeln, Nicola, and Matthias Schündeln, ”Who stays, who goes, who returns? EastWest Migration within Germany since Reunification,” Economics of Transition, 17 (2009) 703-738.

Gruber, Jonathan, ed., Risky Behavior among Youth: An Economic Analysis (Chicago IL: University of Chicago Press). 
Gruber, Jonathan, Phillip B. Levine, and Douglas Staiger, “Abortion Legalization and Child Living Circumstances: Who Is the 'Marginal Child'," Quarterly Journal of Economics, 114 (1999), 263-292.

Heckman, James J., Seong Hyeok Moon, Rodrigo Pinto, Peter A. Sevleyev and Adam Yavitz, “The Rate of Return to the HighScope Perry Preschool Program,” Journal of Public Economics, 94 (2010), 114-128.

Hjalmarsson, Randi, and Matthew Lindquist, "Like Godfather, Like Son: Exploring the Intergenerational Nature of Crime,” Journal of Human Resources, 47 (2012), 550-582.

Hoeve, Machteld, Judith Semon Dubas, Veroni Eichelsheim, Peter van der Laan, Wilma Smeenk and Jan Gerris. "The Relationship Between Parenting and Delinquency: A meta-Analysis,” Journal of Abnormal Child Psychology, 73 (2009), 749-775.

Hunt, Jennifer, "Staunching Emigration from East Germany: Age and the Determinants of Migration,” Journal of the European Economic Association, 4 (2006), 1014-1037.

Joyce, Ted, “Did Legalized Abortion Lower Crime?” Journal of Human Resources, 39 (2004), 1-28.

Joyce, Ted, “A Simple Tests of Abortion and Crime,” Review of Economics and Statistics, 91 (2009), 112-123.

Judt, Tony, Postwar: A History of Europe since 1945, (London, UK: Pimlico).

Kreyenfeld, Michela, "Uncertainties in Femal Employmnet Careers and the Postponement of Parenthood in Germany,” European Sociological Review, 26 (2010), 351-366.

Kempkes, Gerhard "Rapid Demographic Change and the Allocation of Public Education Resources: Evidence from East Germany”, Deutsche Bundesbank Discussion Paper No. 16/2010, 2010. 
Perry, Cynthia, “How do Female Earnings Affect Fertility Decisions?” Massachusetts Institute of Technology, PhD Thesis, 2004.

Pop-Eleches, Christian, "The impact of an abortion ban on socioeconomic outcomes of children: Evidence from Romania,” Journal of Political Economy, 114 (2006), 744773.

Reinheckel, Antje, Kornelia Frank, Wolfgang Weise, and Bernt-Peter Robra, “Effect of ReUnification on Fertility Behaviour in East Germany: A Review of the Evidence Reproductive,” Health Matters, 6 (1998), 122-128.

Rindfuss, Ronald R., John Shelton Reed, and Craig St. John, “A Fertility Reaction to a Historical Event: Southern White Birth Rates and the 1954 Desegregation Ruling,” Science, 201 (1978), 178-180.

Sandner, Malte, "Effects of Early Child Intervention on Child Development and Early Skill Formation. Evidence from a Randomized Controlled Trial,” Hannover University Discussion Paper No 518, 2012.

Sampson, Robert J. and John H. Laub, Crime in the Making: Pathways and Turning Points through Life (Cambridge, MA: Harvard University Press).

Schmitt, Christian, “Gerburten in Ost- und Westdeutschland: erleichtert eine hohe Risikobereitschaft die Entscheidung für ein Kind?” DIW Discussion Paper No. 11.2012, 2012.

Sen, Anindya, “Does Increased Abortion Lead to Lower Crime? Evaluating the Relationship between Crime, Abortion and Fertility,” B.E. Journal of Economic Analysis and Policy, 7 (2007), 48. 
Simons, Ronald L., Frederick O. Lorenz, Rand D. Conger and Chyi-In Wu, "Support from Spouse as Mediator and Moderator of the Disruptive Influence of Economic Strain on Parenting,” Child Development, 63 (1992), 1282-1301.

Sobotka, Tomás, Vegard Skirbekk, and Dimiter Philipov, “Economic Recession and Fertility in the Developed World,” Population and Development Review, 37 (2011), 267-306.

Solon, Gary, Steven Haider and Jeffrey Wooldridge, “What Are We Weighting For?”, NBER Working Paper No. w18859, 2013.

Tracy, Paul E., Marvin E. Wolfgang and Robert M. Figlio, Delinquency Careers in Two Birth Cohorts. (New York, NY: Plenum Press).

United Nations Economic Commission for Europe, "Fertility Decline in the Transition Economics, 1989-1998: Economic and Social Factors Revisited,” Economic Survey of Europe, 1 (2000), 189-207.

van den Bergh, Bea, Eduard Mulder, Maarten Mennes and Vivette Glover, “Antenatal Maternal Anxiety and Stress and the Neurobehavioural Development of the Foetus and Child: Links and Possible Mechanisms. A review," Neuroscience and Biobehavioral Reviews, 29 (2005) 237-258.

Witte, James C. and Gert G. Wagner, "Declining Fertility in East Germany After Unification: A Demographic Response to Socioeconomic Change,” Population and Development Review, 21 (1995): 387-397

Weinhardt, Michael and Jürgen Schupp, “Multi-Itemskalen im SOEP Jugendfragebogen,” DIW Technical Report 60/2011, 2011. 
Table 1 - Proportion of 'Children of the Wall' by Crime Age Groups from 1993 to 2011

\begin{tabular}{lccccccccc}
\hline Age & Under & $6-7$ & $8-9$ & $10-11$ & $12-13$ & $14-15$ & $16-17$ & $18-20$ & $21-22$ \\
Group/ & 6 & & & & & & & & \\
Year & $1 / 2$ & 0 & 0 & 0 & 0 & 0 & 0 & 0 & 0 \\
\hline 1993 & $1 / 2$ & 0 & 0 & 0 & 0 & 0 & 0 & 0 & 0 \\
1994 & $1 / 2$ & 0 & 0 & 0 & 0 & 0 & 0 & 0 & 0 \\
1995 & $1 / 2$ & 0 & 0 & 0 & 0 & 0 & 0 & 0 & 0 \\
1996 & $1 / 3$ & $1 / 2$ & 0 & 0 & 0 & 0 & 0 & 0 & 0 \\
1997 & $1 / 6$ & 1 & 0 & 0 & 0 & 0 & 0 & 0 & 0 \\
1998 & 0 & 1 & $1 / 2$ & 0 & 0 & 0 & 0 & 0 & 0 \\
1999 & 0 & $1 / 2$ & 1 & 0 & 0 & 0 & 0 & 0 & 0 \\
2000 & 0 & 0 & 1 & $1 / 2$ & 0 & 0 & 0 & 0 & 0 \\
2001 & 0 & 0 & $1 / 2$ & 1 & 0 & 0 & 0 & 0 & 0 \\
2002 & 0 & 0 & 0 & 1 & $1 / 2$ & 0 & 0 & 0 & 0 \\
2003 & 0 & 0 & 0 & $1 / 2$ & 1 & 0 & 0 & 0 & 0 \\
2004 & 0 & 0 & 0 & 0 & 1 & $1 / 2$ & 0 & 0 & 0 \\
2005 & 0 & 0 & 0 & 0 & $1 / 2$ & 1 & 0 & 0 & 0 \\
2006 & 0 & 0 & 0 & 0 & 0 & 1 & $1 / 2$ & 0 & 0 \\
2007 & 0 & 0 & 0 & 0 & 0 & $1 / 2$ & 1 & 0 & 0 \\
2008 & 0 & 0 & 0 & 0 & 0 & 0 & 1 & $1 / 3$ & 0 \\
2009 & 0 & 0 & 0 & 0 & 0 & 0 & $1 / 2$ & $2 / 3$ & 0 \\
2010 & 0 & 0 & 0 & 0 & 0 & 0 & 0 & 1 & 0 \\
2011 & 0 & 0 & 0 & 0 & 0 & 0 & 0 & 0 \\
\hline & 0 & 0 & 0 & 0 & 0 & 0 & 0 & 0 \\
\hline
\end{tabular}

Note: ‘Children of the Wall’ are defined as being born in an Eastern Länder between 1991 and 1993. 
Table 2 - Change in Overall Arrest Rates of 'Children of the Wall' Cohorts for All Age Groups, for Under 21s Only, and by Gender

\begin{tabular}{|c|c|c|c|c|c|}
\hline \multirow{3}{*}{$\begin{array}{l}\text { Proportion of Cohort } \\
\text { that are CoW }\end{array}$} & \multicolumn{5}{|c|}{ Log Arrest Rate } \\
\hline & \multicolumn{3}{|c|}{ All } & \multirow{2}{*}{$\begin{array}{c}\text { Men } \\
(4)\end{array}$} & \multirow{2}{*}{$\begin{array}{c}\text { Women } \\
(5)\end{array}$} \\
\hline & (1) & (2) & (3) & & \\
\hline $\begin{array}{l}\text { i - All Age Groups } \\
{[\mathrm{N}=4,275]}\end{array}$ & $\begin{array}{c}0.733^{* * *} \\
(0.083)\end{array}$ & $\begin{array}{c}0.637^{* * *} \\
(0.083)\end{array}$ & $\begin{array}{c}0.634^{* * * *} \\
(0.081)\end{array}$ & $\begin{array}{c}0.637 * * * \\
(0.112)\end{array}$ & $\begin{array}{c}0.638^{* * *} \\
(0.084)\end{array}$ \\
\hline $\begin{array}{l}\text { ii -Under 21s Only } \\
\text { [ } N=2,280]\end{array}$ & $\begin{array}{c}0.568 * * * \\
(0.046)\end{array}$ & $\begin{array}{c}0.500^{* * *} \\
(0.084)\end{array}$ & $\begin{array}{c}0.425^{* * *} \\
(0.089)\end{array}$ & $\begin{array}{c}0.418 * * * \\
(0.081)\end{array}$ & $\begin{array}{c}0.480^{* * *} \\
(0.072)\end{array}$ \\
\hline $\begin{array}{l}\text { Age Group, Land, and } \\
\text { Year Dummies }\end{array}$ & Yes & Yes & Yes & Yes & Yes \\
\hline $\begin{array}{l}\text { Land Time Varying } \\
\text { Controls }\end{array}$ & No & Yes & Yes & Yes & Yes \\
\hline $\begin{array}{l}\text { Land Specific Time } \\
\text { Trends }\end{array}$ & No & No & Yes & Yes & Yes \\
\hline
\end{tabular}

Note: The Land time varying controls are annual measures of overall unemployment, youth unemployment rates; proportion foreign born by age groups; and number of police officers per 1,000 population. Robust standard error clustered at the Land level in parenthesis. Estimates are weighted by population size. $*$, **, and *** denote respectively significance at the 1,5 , and 5 percent level. 
Table 3 - Change in Crime Specific Arrest Rates of 'Children of the Wall' Cohorts for Under 21s Only, by Gender

\begin{tabular}{|c|c|c|c|c|c|c|}
\hline \multirow[b]{2}{*}{$\begin{array}{l}\text { Proportion of } \\
\text { Cohort that are CoW }\end{array}$} & \multicolumn{6}{|c|}{ Log Arrest Rate } \\
\hline & $\begin{array}{c}\text { All } \\
\text { Crimes }\end{array}$ & $\begin{array}{l}\text { Theft \& } \\
\text { Burglary }\end{array}$ & $\begin{array}{l}\text { Violent } \\
\text { \& Sexual }\end{array}$ & $\begin{array}{c}\text { Criminal } \\
\text { Damage }\end{array}$ & $\begin{array}{l}\text { Fraud \& } \\
\text { Forgery }\end{array}$ & $\begin{array}{c}\text { Drug } \\
\text { Offences }\end{array}$ \\
\hline i - Under 21s, All & $\begin{array}{c}0.425 * * * \\
(0.078) \\
{[49.00]}\end{array}$ & $\begin{array}{c}0.420 * * * \\
(0.133) \\
{[24.09]}\end{array}$ & $\begin{array}{c}0.393 * * * \\
(0.107) \\
{[9.79]}\end{array}$ & $\begin{array}{c}0.490 * * * \\
(0.066) \\
{[9.22]}\end{array}$ & $\begin{array}{c}0.557 * * \\
(0.208) \\
{[3.86]}\end{array}$ & $\begin{array}{c}0.273 \\
(0.197) \\
{[3.44]}\end{array}$ \\
\hline ii - Under 21s, Males & $\begin{array}{c}0.418 * * * \\
(0.086) \\
{[74.83]}\end{array}$ & $\begin{array}{c}0.462 * * * \\
(0.140) \\
{[35.35]}\end{array}$ & $\begin{array}{c}0.356^{* * *} \\
(0.108) \\
{[16.50]}\end{array}$ & $\begin{array}{c}0.510 * * * \\
(0.074) \\
{[16.19]}\end{array}$ & $\begin{array}{c}0.512 * * \\
(0.221) \\
{[5.30]}\end{array}$ & $\begin{array}{c}0.207 \\
(0.188) \\
{[5.80]}\end{array}$ \\
\hline iii - Under 21s, Females & $\begin{array}{c}0.481 * * * \\
(0.101) \\
{[21.47]}\end{array}$ & $\begin{array}{c}0.317 * * \\
(0.125) \\
{[12.10]}\end{array}$ & $\begin{array}{c}0.474 * * * \\
(0.146) \\
{[2.64]}\end{array}$ & $\begin{array}{c}0.651^{* * *} \\
(0.080) \\
{[1.80]}\end{array}$ & $\begin{array}{c}0.340^{*} \\
(0.192) \\
{[2.33]}\end{array}$ & $\begin{array}{c}0.438^{*} \\
(0.204) \\
{[0.93]}\end{array}$ \\
\hline $\begin{array}{l}\text { Age Group, Land, and } \\
\text { Year Dummies }\end{array}$ & Yes & Yes & Yes & Yes & Yes & Yes \\
\hline $\begin{array}{l}\text { Land Time Varying } \\
\text { Controls }\end{array}$ & Yes & Yes & Yes & Yes & Yes & Yes \\
\hline $\begin{array}{l}\text { Land Specific Time } \\
\text { Trends }\end{array}$ & Yes & Yes & Yes & Yes & Yes & Yes \\
\hline
\end{tabular}

Note: The Land time varying controls are yearly measures of overall unemployment, youth unemployment rates; proportion foreign born by age groups; and number of police officers per 1,000 population. Estimates are weighted by Land and age group population size. Robust standard error clustered at the Land level in parenthesis. *, **, and *** denote respectively significance at the 1,5 , and 5 percent level. Average baseline arrest rates per 1,000 population in Eastern Länder when no cohorts are treated are in square brackets []. 
Table 4 - Robustness Checks of Cohort Level Crime Results

\begin{tabular}{|c|c|c|}
\hline Description of Robustness Check Specification & $\begin{array}{l}\text { Log Arrest } \\
\text { Rate }\end{array}$ & $\begin{array}{l}\text { Age Groups } \\
\text { [Sample Size] }\end{array}$ \\
\hline $\begin{array}{l}\text { 1- Internal migration: control for of proportion of } \\
\text { potential mothers moving from East to West }\end{array}$ & $\begin{array}{c}0.424 * * * \\
(0.089)\end{array}$ & $\begin{array}{l}\text { Under 21s } \\
{[2,280]}\end{array}$ \\
\hline $\begin{array}{l}\text { 2- Exclude all cohorts born after } 1993 \text { (which could be } \\
\text { positively selected because of delayed fertility) }\end{array}$ & $\begin{array}{c}0.596^{* * * *} \\
(0.143)\end{array}$ & $\begin{array}{c}\text { Under 21s } \\
{[1,545]}\end{array}$ \\
\hline $\begin{array}{l}\text { 3- Exclude all cohorts born after } 1993 \text { and only include } \\
6 \text { cohorts before } 1991 \text { (i.e. } 1985 \text { to 1990) }\end{array}$ & $\begin{array}{c}0.621 * * * \\
(0.147)\end{array}$ & $\begin{array}{l}\text { Under 21s } \\
\quad[990]\end{array}$ \\
\hline $\begin{array}{l}\text { 3- Exclude all Cohorts born after } 1993 \text { and only include } \\
3 \text { cohorts before } 1991 \text { (i.e. } 1988 \text { to 1990) }\end{array}$ & $\begin{array}{l}0.509 * * * \\
(0.124)\end{array}$ & $\begin{array}{l}\text { Under 21s } \\
\quad[810]\end{array}$ \\
\hline $\begin{array}{l}\text { 4- Extending CoW sample to also include children born } \\
\text { East in } 1990 \text { (i.e. } 1990 \text { to 1993) }\end{array}$ & $\begin{array}{l}0.342^{* * *} \\
(0.065)\end{array}$ & $\begin{array}{l}\text { Under 21s } \\
{[2,280]}\end{array}$ \\
\hline $\begin{array}{l}\text { 5- Extending CoW sample to also include children born } \\
\text { East in } 1994 \text { (i.e. } 1990 \text { to 1994) }\end{array}$ & $\begin{array}{c}0.422 * * * \\
(0.095)\end{array}$ & $\begin{array}{l}\text { Under 21s } \\
{[2,280]}\end{array}$ \\
\hline $\begin{array}{l}\text { 6- Placebo: Treated Born from } 1987 \text { to } 1989 \\
\text { (Post-1990 Cohorts Dropped as Treated) }\end{array}$ & $\begin{array}{c}0.056 \\
(0.057)\end{array}$ & $\begin{array}{l}\text { Under 21s } \\
{[2,115]}\end{array}$ \\
\hline
\end{tabular}

Note: All regressions include Land time varying controls overall unemployment, youth unemployment rate; proportion foreign born by age groups; and number of police officers per 1,000 population, and Land specific time trends. Cells are weighted by Land, age group and population size. Robust standard error clustered at the Land level in parenthesis. * ${ }^{* *}$, and *** denote respectively significance at the 1,5 , and 10 percent level. 
Table 5 - Positive or Negative Selection of Fertility Decision Differences in Characteristics of Mothers of the 'Children of the Wall'

\begin{tabular}{lccccc}
\hline & \multicolumn{5}{c}{ Sample: All Women who Had a Child } \\
& $\begin{array}{c}\text { Age } \\
\text { of Mothers }\end{array}$ & $\begin{array}{c}\text { Years of } \\
\text { Education }\end{array}$ & $\begin{array}{c}\text { Completed } \\
\text { High School }\end{array}$ & $\begin{array}{c}\text { Married or } \\
\text { Cohabiting }\end{array}$ & $\begin{array}{c}\text { Economic } \\
\text { Activity }\end{array}$ \\
\hline Child of the Wall & $-0.875^{* * *}$ & $-0.982^{* * *}$ & $-0.107^{* * *}$ & $-0.090^{* * *}$ & $-0.115^{* * *}$ \\
(i.e. East * 1991-93) & $(0.235)$ & $(0.157)$ & $(0.026)$ & $(0.030)$ & $(0.017)$ \\
Birth East & $-2.657^{* * *}$ & $0.686^{* * *}$ & $0.124^{* * *}$ & $-0.087^{* * *}$ & $0.068^{* * *}$ \\
& $(0.131)$ & $(0.099)$ & $(0.009)$ & $(0.011)$ & $(0.013)$ \\
Birth 1991-93 & $0.291^{*}$ & $0.173^{*}$ & $0.015^{*}$ & 0.020 & -0.017 \\
Number of Children & $(0.168)$ & $(0.099)$ & $(0.008)$ & $(0.013)$ & $(0.011)$ \\
Year Birth (Quadratic) & Yes & Yes & Yes & Yes & Yes \\
Cohort Size Weight & Yes & Yes & Yes & Yes & Yes \\
Sample Size & Yes & Yes & Yes & Yes & Yes \\
\hline
\end{tabular}

Note: CoW is the interaction of having a child between 1991 and 1993 who was born in an East German Land. Robust standard errors clustered by child year of birth and East/West reported in parenthesis. *, **, and *** denote respectively significance at the 1, 5, and 10 percent level. Source: GSOEP 1990 to 2011. 
Table 6 - Educational Attainment and Maternal Relationship at Age 17 of the 'Children of the Wall'

\begin{tabular}{|c|c|c|c|c|c|c|}
\hline & \multicolumn{3}{|c|}{ Educational Attainment } & \multicolumn{3}{|c|}{ Maternal Relationship } \\
\hline $\begin{array}{l}\text { Child of the Wall } \\
\text { (i.e. East } * 1991-93 \text { ) }\end{array}$ & $\begin{array}{l}-0.013 \\
(0.011)\end{array}$ & $\begin{array}{c}0.051^{* * *} \\
(0.021)\end{array}$ & $\begin{array}{r}0.226 * * \\
(0.090)\end{array}$ & $\begin{array}{c}-0.110^{* *} \\
(0.053)\end{array}$ & $\begin{array}{c}-0.141^{* *} \\
(0.064)\end{array}$ & $\begin{array}{c}-0.299 * * \\
(0.138)\end{array}$ \\
\hline Born East & $\begin{array}{l}-0.002 \\
(0.008)\end{array}$ & $\begin{array}{c}-0.046 * * \\
(0.019)\end{array}$ & $\begin{array}{l}-0.120 * \\
(0.060)\end{array}$ & $\begin{array}{l}0.046 * \\
(0.023)\end{array}$ & $\begin{array}{c}0.023 \\
(0.023)\end{array}$ & $\begin{array}{l}-0.077 \\
(0.092)\end{array}$ \\
\hline Born 1991-1993 & $\begin{array}{l}-0.006 \\
(0.010)\end{array}$ & $\begin{array}{c}-0.030 * * \\
(0.015)\end{array}$ & $\begin{array}{l}-0.009 \\
(0.086)\end{array}$ & $\begin{array}{c}0.036 \\
(0.031)\end{array}$ & $\begin{array}{l}-0.016 \\
(0.027)\end{array}$ & $\begin{array}{c}0.074 \\
(0.096)\end{array}$ \\
\hline Single Mother Hhld & Yes & Yes & Yes & Yes & Yes & Yes \\
\hline Year Birth (Quadratic) & Yes & Yes & Yes & Yes & Yes & Yes \\
\hline Cohort Size Weights & Yes & Yes & Yes & Yes & Yes & Yes \\
\hline Sample Size & 3,292 & 3,375 & 3,326 & 3,332 & 3,299 & 3,234 \\
\hline
\end{tabular}

Note: CoW is the interaction of being born between 1991 and 1993 and being born in East Germany. Robust standard errors clustered by child year of birth and East/West reported in parenthesis. *, **, and *** denote respectively significance at the 1, 5, and 10 percent level. All information is taken from survey questions asked at age 17 in the GSOEP between 1990 and 2011. Below Average Scores indicates that the individual reported scores in math and German below the mean in his cohort. Mother Important in Life derives from the answer to a 4-points scale question which we dichotomize by grouping 'important' and 'very important' categories and the 'less important' and 'not important at all' ones together. Mother Loves Me comes from the question "Mother Shows that she Loves you” from which we generate a dummy variable which is one if the youths respond 'very often' and zero otherwise. Supportive Parenting is derived from a multi-item scale of 9 questions as described in Weinhardt and Schupp (2011) 


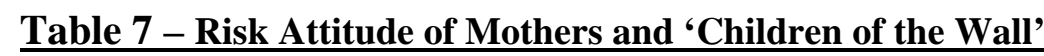

\begin{tabular}{|c|c|c|c|c|c|c|}
\hline & \multicolumn{4}{|c|}{$\begin{array}{c}\text { Mothers } \\
\text { (birth } 1980 \text { to 2000) }\end{array}$} & \multicolumn{2}{|c|}{$\begin{array}{c}\text { Children } \\
\text { (born } 1980 \text { to 1994) }\end{array}$} \\
\hline & $\begin{array}{c}\text { Overall } \\
\text { Risk Level }\end{array}$ & $\begin{array}{c}\text { Overall } \\
\text { Risk Lover }\end{array}$ & $\begin{array}{c}\text { "Bad" } \\
\text { Risk Lover }\end{array}$ & $\begin{array}{c}\text { “Good” } \\
\text { Risk Lover }\end{array}$ & $\begin{array}{c}\text { Overall } \\
\text { Risk Level }\end{array}$ & $\begin{array}{c}\text { Overall } \\
\text { Risk Lover }\end{array}$ \\
\hline $\begin{array}{l}\text { Child of the Wall } \\
\text { (i.e. East * 1991-93) }\end{array}$ & $\begin{array}{c}0.289 * * * \\
(0.094)\end{array}$ & $\begin{array}{c}0.086^{* * *} \\
(0.030)\end{array}$ & $\begin{array}{c}0.130 * * * \\
(0.032)\end{array}$ & $\begin{array}{l}0.028 \\
(0.018)\end{array}$ & $\begin{array}{l}0.454^{* *} \\
(0.190)\end{array}$ & $\begin{array}{l}0.081^{* *} \\
(0.040)\end{array}$ \\
\hline Birth/Born East & $\begin{array}{l}0.129 * * \\
(0.053)\end{array}$ & $\begin{array}{l}0.020^{*} \\
(0.012)\end{array}$ & $\begin{array}{l}0.003 \\
(0.012)\end{array}$ & $\begin{array}{l}0.016^{*} \\
(0.009)\end{array}$ & $\begin{array}{l}-0.004 \\
(0.056)\end{array}$ & $\begin{array}{l}-0.009 \\
(0.015)\end{array}$ \\
\hline Birth/Born 1991-93 & $\begin{array}{l}0.088 \\
(0.075)\end{array}$ & $\begin{array}{c}0.004 \\
(0.008)\end{array}$ & $\begin{array}{l}-0.033 \\
(0.022)\end{array}$ & $\begin{array}{l}0.005 \\
(0.009)\end{array}$ & $\begin{array}{l}-0.191 * \\
(0.104)\end{array}$ & $\begin{array}{l}-0.028 \\
(0.025)\end{array}$ \\
\hline Male Dummy & No & No & No & No & Yes & Yes \\
\hline Age (Quadratic) & Yes & Yes & Yes & Yes & Yes & Yes \\
\hline Years of Education & Yes & Yes & Yes & Yes & Yes & Yes \\
\hline Year Birth (Quadratic) & Yes & Yes & Yes & Yes & Yes & Yes \\
\hline Cohort Size Weights & Yes & Yes & Yes & Yes & Yes & Yes \\
\hline Sample Size & \multicolumn{2}{|c|}{11,076} & \multicolumn{2}{|c|}{8,413} & \multicolumn{2}{|c|}{5,815} \\
\hline
\end{tabular}

Note: CoW is the interaction of having had a child for mothers and for being born between 1991 and 1993 in East Germany. Robust standard errors clustered by child year of birth and East/West reported in parenthesis.*, **, and *** denote respectively significance at the 1, 5, and 10 percent level. Source GSOEP between 1990 to 2011.Risk attitude measures come from the average of the 2004, 2006, 2008, 2009, and 2010 of questions on the willingness to take risk ranked between 0 (minimum) and 10 (maximum). “Bad” Risk is derived from the willingness to take risk 'while driving' and 'with own health' and “Good” Risk is derived from willingness to take 'financial risk'. These risk specific questions were only asked in 2004 and 2009. 
Table 8: Maternal Relationship and Risk Attitude of Siblings of the 'Children of the Wall'

\begin{tabular}{|c|c|c|c|c|c|}
\hline & \multicolumn{3}{|c|}{ Maternal Relationship } & \multicolumn{2}{|c|}{ Risk Attitude } \\
\hline & Important & Loves & $\begin{array}{l}\text { Supportive } \\
\text { Parenting }\end{array}$ & $\begin{array}{c}\text { Overall } \\
\text { Risk Level }\end{array}$ & $\begin{array}{c}\text { Overall } \\
\text { Risk Lover }\end{array}$ \\
\hline $\begin{array}{l}\text { Sibling of a Child of the } \\
\text { Wall (born } 1980 \text { to 1991) }\end{array}$ & $\begin{array}{c}-0.168 * * * \\
(0.062)\end{array}$ & $\begin{array}{c}-0.148 * * * \\
(0.048)\end{array}$ & $\begin{array}{l}-0.640^{* * *} \\
(0.193)\end{array}$ & $\begin{array}{l}0.167^{*} \\
(0.094)\end{array}$ & $\begin{array}{l}0.081^{*} \\
(0.047)\end{array}$ \\
\hline Born East & $\begin{array}{c}0.049 * * \\
(0.022)\end{array}$ & $\begin{array}{c}0.038 \\
(0.022)\end{array}$ & $\begin{array}{l}0.084^{*} \\
(0.043)\end{array}$ & $\begin{array}{l}-0.021 \\
(0.037)\end{array}$ & $\begin{array}{c}0.013 \\
(0.015)\end{array}$ \\
\hline Controls & Yes & Yes & Yes & Yes & Yes \\
\hline Cohort Size Weights & Yes & Yes & Yes & Yes & Yes \\
\hline Sample Size & 3,292 & 3,375 & 3,326 & 3,318 & 3,332 \\
\hline
\end{tabular}


Figure 1: Annual Crude Birth Rate per 1,000 Women from 1950 and 2008

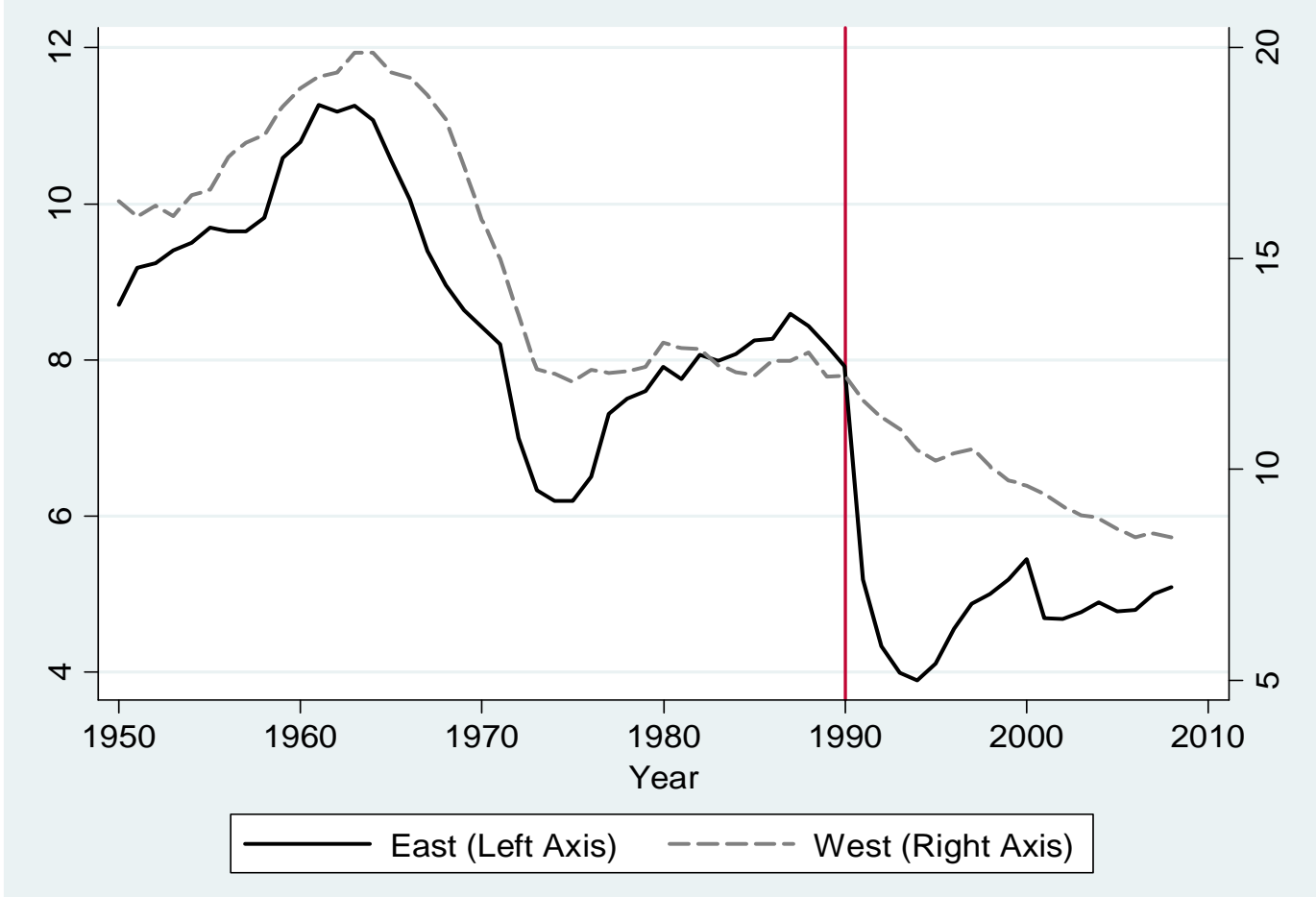

Notes: Authors own calculations based administrative population data from the Federal Institute for Population Research (http://www.bib-demografie.de)

Figure 2: Year-on-Year Changes in Crude Birth Rates between East and West Germany

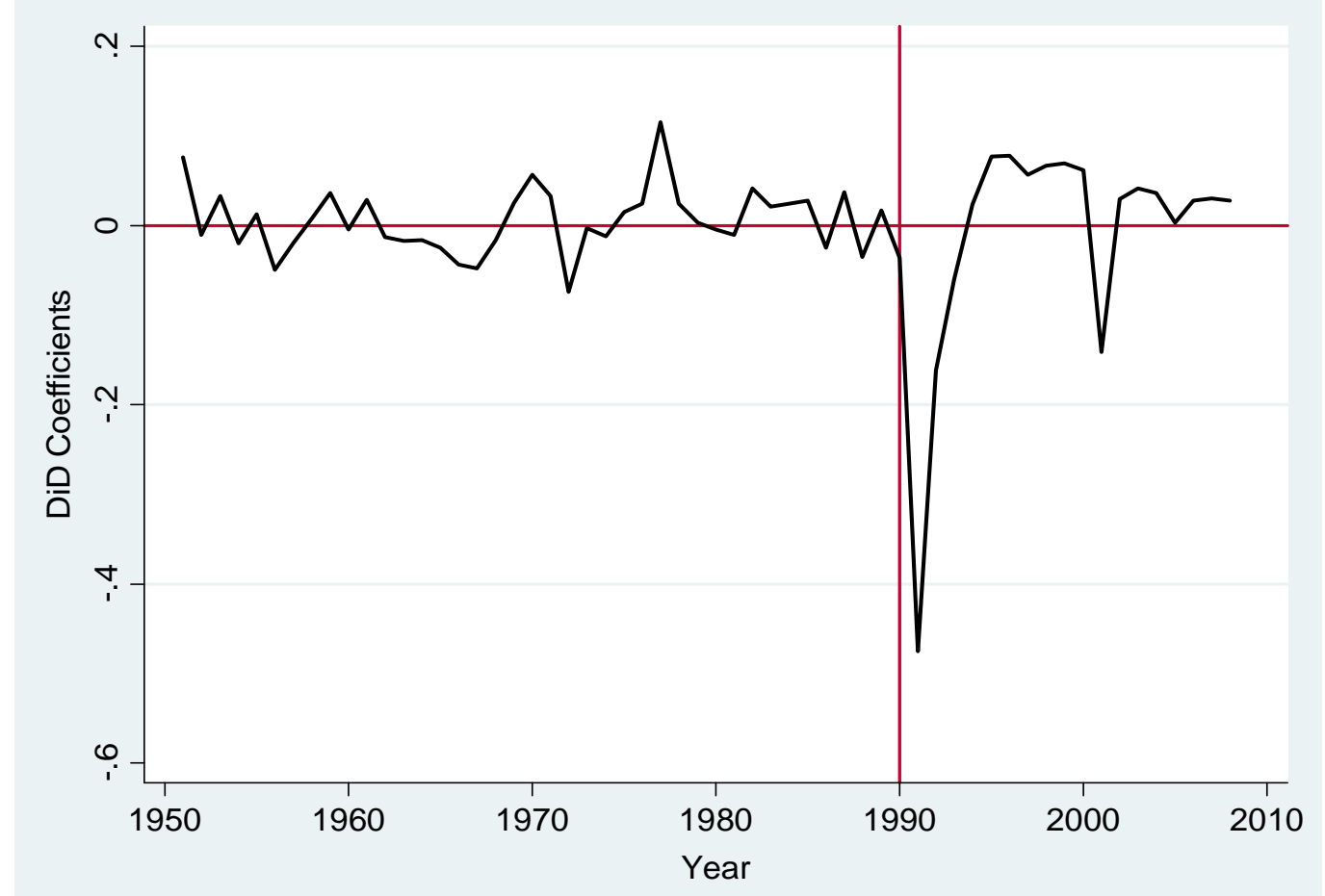

Notes: Graph shows differences-in-differences coefficients year-on-year crude birth rates between East and West Germany calculated from the data presented in Figure 1. 
Figure 3: Monthly Number of Births in East and West Germany from 1990 to 2000

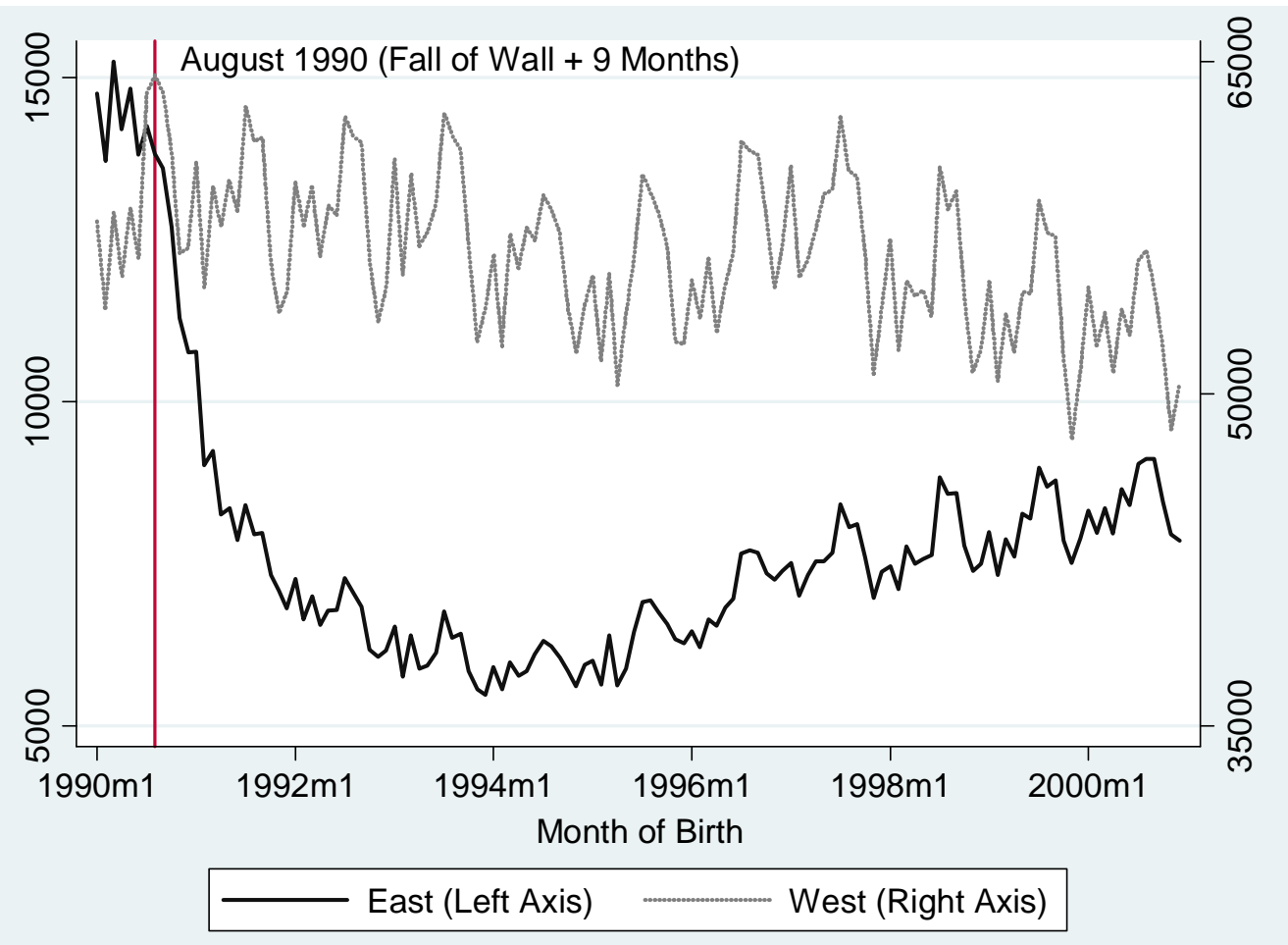

Notes: Administrative birth data from the Federal Institute for Population Research

Figure 4: Difference in the Proportion of East and West Germans who are Very Worried about the Economy or Childcare from 1990 to 1996

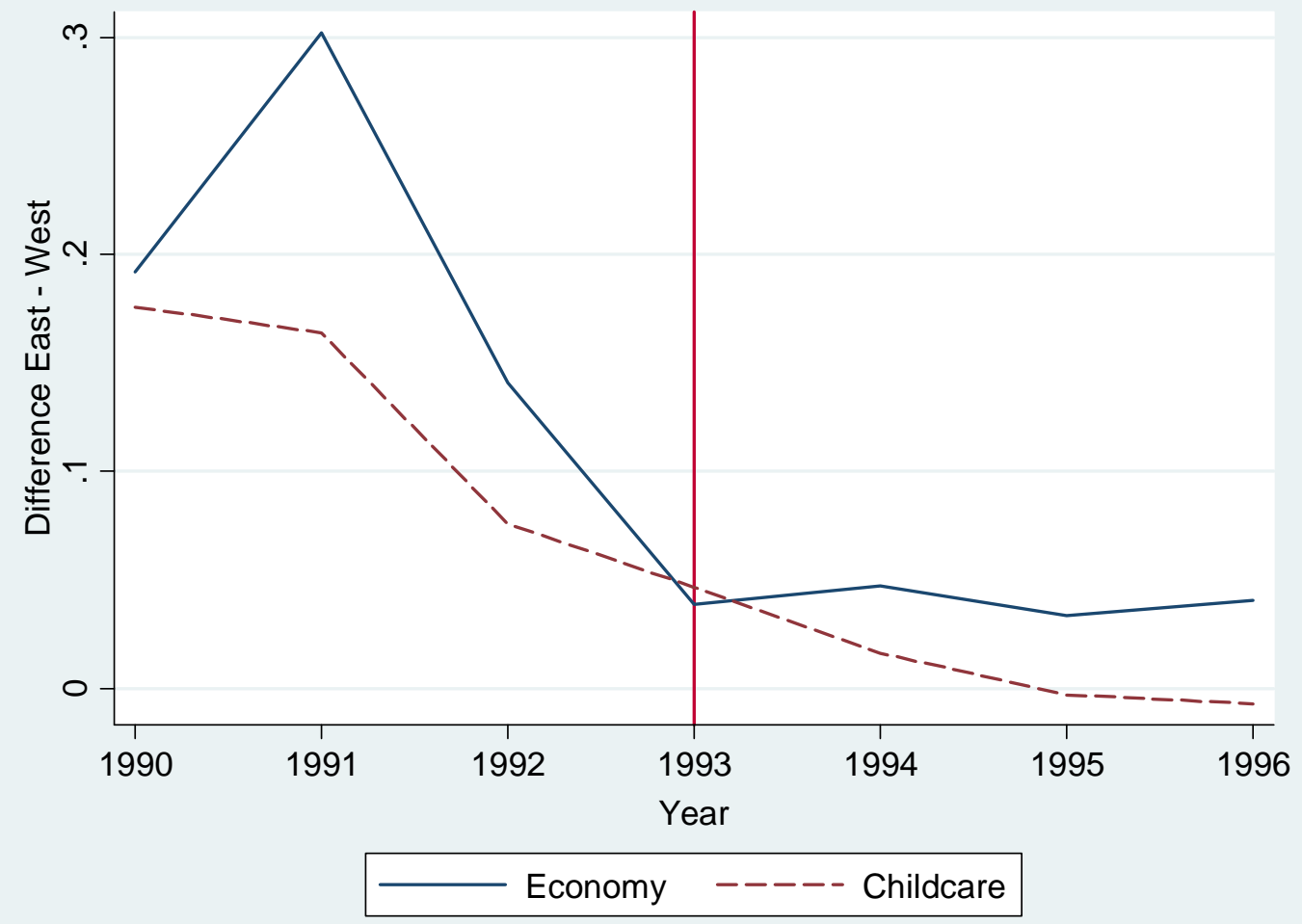

Note: The graphs are based on the difference in the proportion of East and West Germans responding 'Very' (other possible answers: 'Somewhat' or 'Not at all') to questions asked yearly in GSOEP about individual level of worry about "the general economic development" and "childcare availability". 
Figure 5: Arrest Rate per 1,000 Population in East and West Germany for Cohorts Aged 6 to 7, 10 to 11, and 16 to 17 from 1993 to 2011

A] Age group 6-7

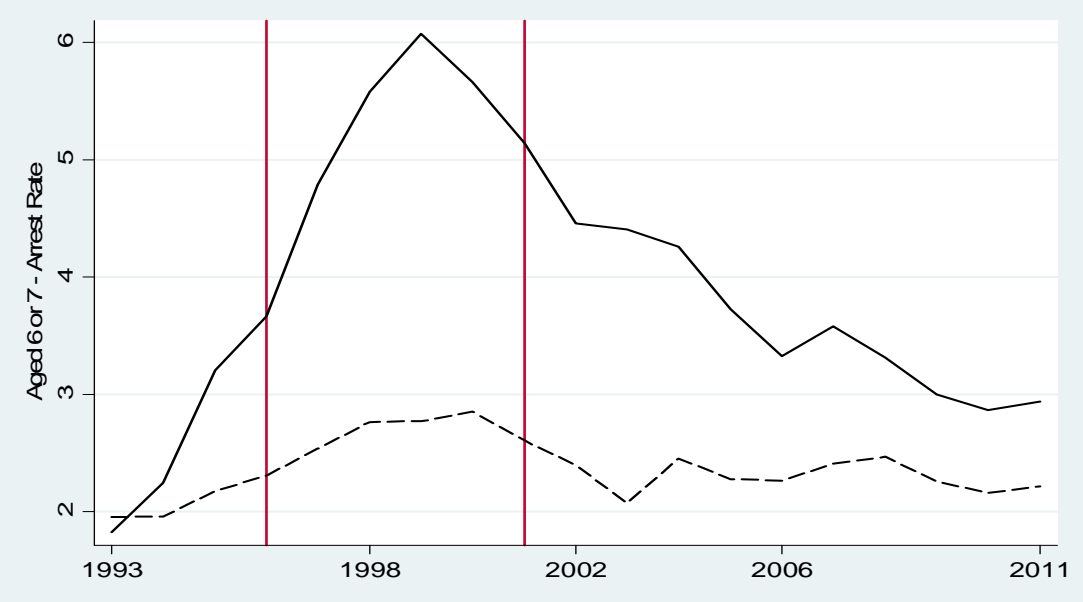

B] Age group 10-11

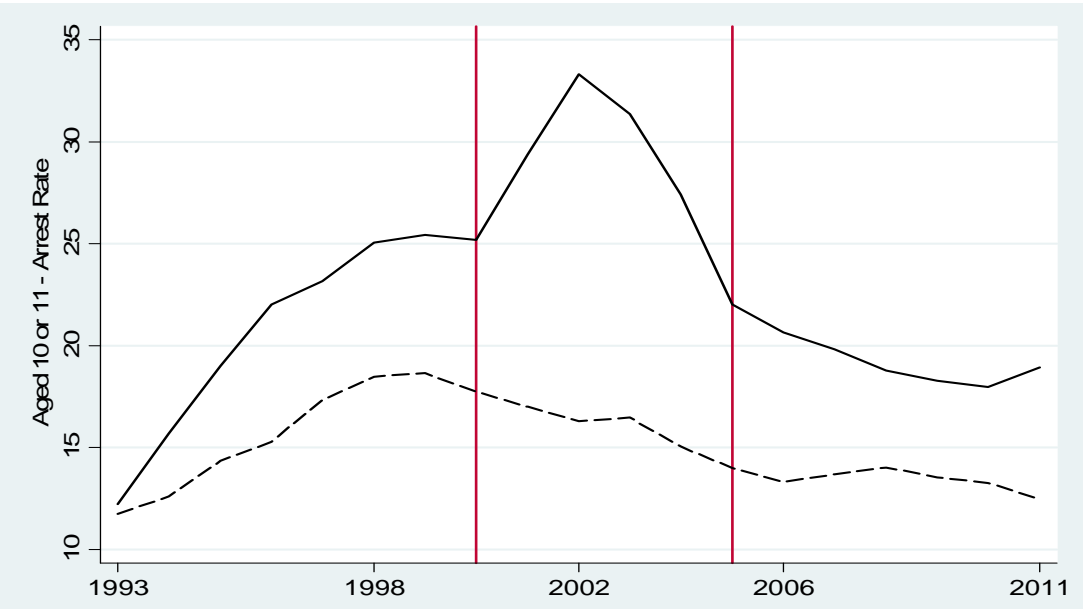

C] Age group 16-17

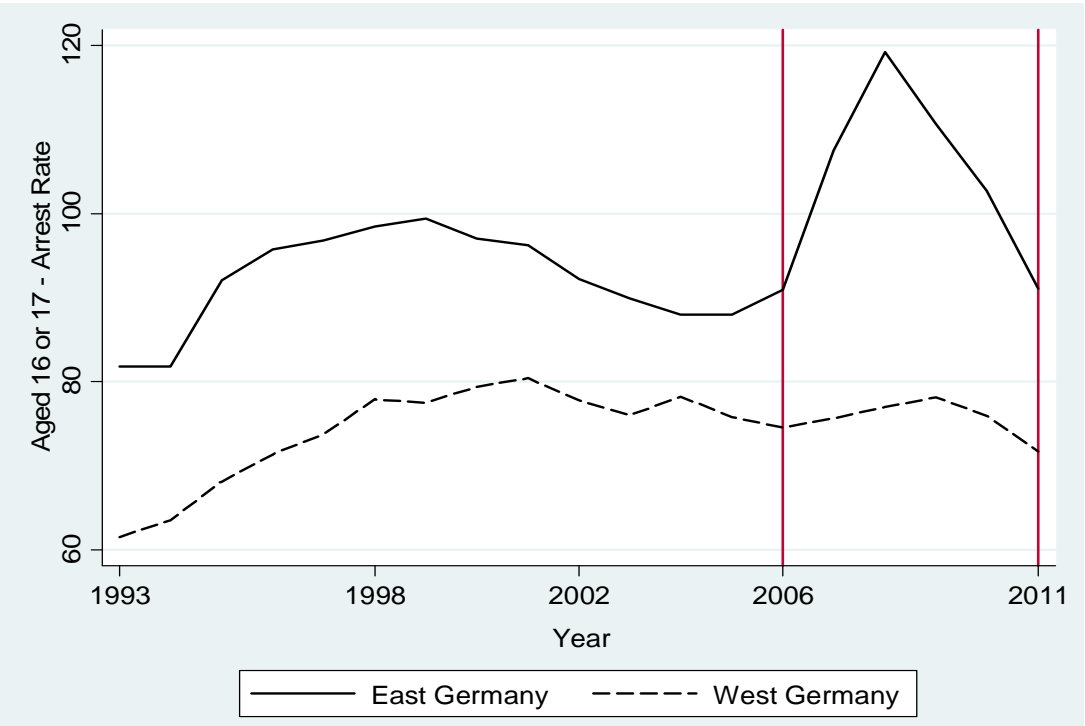

Notes: Author's own calculation from administrative arrest data by two year age groups at the Land level provided by the Federal Criminal Police Office (www.bka.de) 
Figure 6: Economic Uncertainty and Fertility Decision: Probability of Having a Child by Economic Worry and Education Level

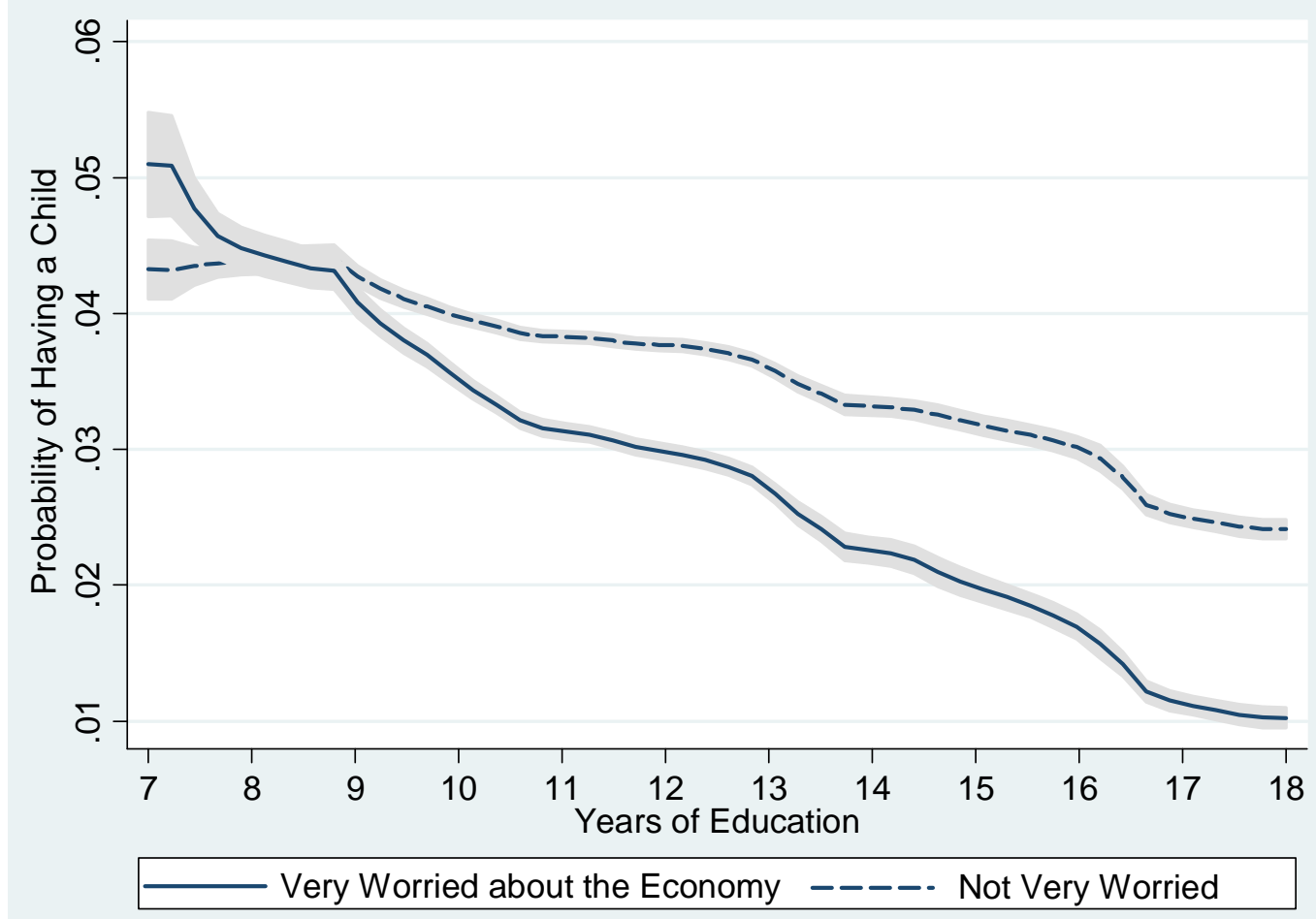

Note: The graph plots the estimated probability of having a child in the period 1991/93 separately for individuals reported to be very worried about the economy ('very' $=1$ and 'somewhat'/'never $=0$ ) or not, by years of education for all women aged 17 to 47 surveyed in GSOEP during this period. The probit model which generates these coefficients also includes education, age and year dummies. The grey area represents the 95 percent confidence intervals. 